\title{
Seabed foraging by Antarctic krill: Implications for stock assessment, bentho-pelagic coupling, and the vertical transfer of iron
}

\author{
Katrin Schmidt, ${ }^{a},{ }^{*}$ Angus Atkinson, ${ }^{a}$ Sebastian Steigenberger, ${ }^{b}$ Sophie Fielding, ${ }^{a}$ \\ Margaret C. M. Lindsay, ${ }^{c}$ David W. Pond, ${ }^{a}$ Geraint A. Tarling, ${ }^{a}$ Thor A. Klevjer, ${ }^{\mathrm{d}}$

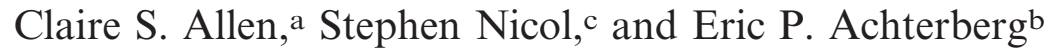 \\ a British Antarctic Survey, Natural Environment Research Council, High Cross, Cambridge, United Kingdom \\ b University of Southampton, National Oceanography Centre Southampton, Southampton, United Kingdom \\ c Australian Antarctic Division, Kingston, Tasmania, Australia \\ d Department of Biology, University of Oslo, Blindern, Oslo, Norway
}

\begin{abstract}
A compilation of more than 30 studies shows that adult Antarctic krill (Euphausia superba) may frequent benthic habitats year-round, in shelf as well as oceanic waters and throughout their circumpolar range. Net and acoustic data from the Scotia Sea show that in summer 2-20\% of the population reside at depths between 200 and $2000 \mathrm{~m}$, and that large aggregations can form above the seabed. Local differences in the vertical distribution of krill indicate that reduced feeding success in surface waters, either due to predator encounter or food shortage, might initiate such deep migrations and results in benthic feeding. Fatty acid and microscopic analyses of stomach content confirm two different foraging habitats for Antarctic krill: the upper ocean, where fresh phytoplankton is the main food source, and deeper water or the seabed, where detritus and copepods are consumed. Krill caught in upper waters retain signals of benthic feeding, suggesting frequent and dynamic exchange between surface and seabed. Krill contained up to $260 \mathrm{nmol}$ iron per stomach when returning from seabed feeding. About $5 \%$ of this iron is labile, i.e., potentially available to phytoplankton. Due to their large biomass, frequent benthic feeding, and acidic digestion of particulate iron, krill might facilitate an input of new iron to Southern Ocean surface waters. Deep migrations and foraging at the seabed are significant parts of krill ecology, and the vertical fluxes involved in this behavior are important for the coupling of benthic and pelagic food webs and their elemental repositories.
\end{abstract}

Vertical migration by zooplankton, fish, or diving vertebrates is a universal feature of aquatic environments. Key to these migrations is the fact that water layers with the preferred food often incur higher risk of predation or physiological stress and are therefore vacated for large parts of the day. Many herbivorous and omnivorous mesozooplankton species feed on phytoplankton near the surface at night but use deeper water as a daytime refuge from visual predators (Hays 2003). Conversely, marine mammals such as sperm whales dive to depths of over $1000 \mathrm{~m}$ to feed on deep-sea squid but regularly return to the surface to breathe (Watwood et al. 2006). Carnivorous chaetognaths and fish often follow the nocturnal migrations of their prey and therefore become migrators themselves (Pearre 2003).

On an individual level, the migrations provide a trade-off between nutrition and survival, but implications arise for the whole ecosystem due to the large biomass of heterotrophs involved. A major consequence of vertical migrations is the redistribution of organic matter and nutrients when feeding locations differ from those of excretion, defecation, or consumption of migrants. Thus, vertical migration is one component of the "biological pump" that draws carbon into the deep ocean (Longhurst and Harrison 1989). On the other hand, migrating animals can also reintroduce nutrients and carbon from depth back

\footnotetext{
* Corresponding author: kasc@bas.ac.uk
}

up into the photic zone. Cladocerans, for instance, have been found to increase phosphorus concentrations in the epilimnion after feeding on algae in the hypolimnion (Haupt et al. 2010); nocturnally ascending mysids release trace metals into the water column after feeding on lake sediments during the day (Song and Breslin 1999); and sperm whales defecate iron-rich feces into the photic zone when returning from deep-sea foraging (Lavery et al. 2010).

Ecological facets of vertical migration are no less complex than its biogeochemistry. The migration behavior of a species can change with life history stage, season, and location (Haney 1988; Ohman 1988). Some zooplankton species are strong migrants, some migrate rarely, while for others the behavior is still debated. Antarctic krill (Euphausia superba, hereafter "krill"), for instance, is considered an epipelagic species with the bulk biomass being centered within the upper $150 \mathrm{~m}$ of the water column (Demer and Hewitt 1995; Lascara et al. 1999) and with diurnal vertical migrations either of small amplitude or absent (Godlewska 1996). Therefore, routine krill surveys for fishery and ecosystem management have generally focused only on the upper $200 \mathrm{~m}$ (Hewitt et al. 2004; Siegel 2005)

This traditional view of krill being epipelagic was challenged by images taken from a remotely operated vehicle, which showed krill feeding at the seabed in water depths of up to $3500 \mathrm{~m}$ (Clarke and Tyler 2008). Neither their foraging at the seabed (Kawaguchi et al. 1986) nor 
occasional descent to great depth (Marr 1962; Lancraft et al. 1989; Daly and Macaulay 1991) were novel findings, but the surprising aspect was that krill reached $3500 \mathrm{~m}$ of depth in good physiological condition and most likely migrated this distance to feed (Clarke and Tyler 2008). Until now it remains unclear if these extremely deep krill were "ecological outliers" or a rare glimpse of a widespread behavior, missed with standard sampling procedures (Brierley 2008).

The current biomass of Antarctic krill is 100-500 million tonnes (Siegel 2005; Atkinson et al. 2009). Thus, even if only a small part of this massive stock commutes between surface and seabed, it will have fundamental implications for the bentho-pelagic coupling of food webs and nutrient pools. However, background information on deep migrations and benthic feeding by krill - the causes, the nutritional benefit, and the part of the population involved - are still missing; and, therefore, the phenomenon is not incorporated into krill energy budgets (Fach et al. 2006), life history models (Nicol 2006), or stock assessments (Siegel 2005).

We approached these challenging questions by applying multiple methods. To assess the overall circumpolar prevalence and seasonality of benthic migrations, we compiled all existing information on krill-seabed interactions, including unpublished data and our own photographic survey. To estimate the proportion of krill found below $200 \mathrm{~m}$, possibly in transit to or from the seabed, we used large datasets on vertical distribution from both nets and acoustics. To establish the nutritional gain from seabed foraging, we analyzed the stomach content of krill from 69 stations in the Scotia Sea and neighboring Bransfield Strait. Finally, to assess the potential implications in terms of elemental cycling, we quantified the amount of iron that krill return to the surface after benthic feeding.

\section{Methods}

Photographic survey - A photographic survey of the seabed was conducted at 33 stations off East Antarctica between 16 December 2007 and 30 January 2008 on the R/V Aurora Australis. The water depth ranged from 228 to $1625 \mathrm{~m}$. A video camera (Canon EOS single-lens reflex camera, 8 megapixel) was attached to a beam trawl and towed $\sim 1 \mathrm{~m}$ above the seabed with a constant speed of $\sim 1.85 \mathrm{~km} \mathrm{~h}^{-1}$. Still images were taken every $10-20 \mathrm{~s}$, with 1-296 images per station (median: 47, total: 2408). For each image, presence or absence of euphausiids was recorded.

Net hauls - Data from "krillbase" (Atkinson et al. 2008, 2009) were used to study the deep vertical distribution of postlarval krill. This database is a circumpolar compilation of untargeted net hauls, either oblique or vertical. It spans the October-April period, although three-quarters of the data are from the most intensively sampled mid-summer months of December, January, and February (see Atkinson et al. 2008 for further details). For this study we have additionally included vertical profiles given in Marin et al. (1991), Piatkowski et al. (1994), Taki et al. (2008), and recent unpublished data from the British Antarctic Survey. The net hauls were divided into shelf and ocean areas using the 1000-m isobaths as a boundary. Within the categories "shelf" and "ocean," the hauls were further divided into seven nominal depth strata, according to the top sampling depth of the net (i.e., 0-100, 100-200, 200-300, 300-400, $400-500,500-1000$, and $>1000 \mathrm{~m}$ ). Note that the bottom depths of the net may have extended deeper than these nominal strata suggest (e.g., a $0-200 \mathrm{~m}$ haul would be classified as within top depth range, $0-100 \mathrm{~m}$ ). Thus, for calculation purposes, we made the conservative assumption that all krill caught in a haul covering several of these seven depth strata were in the uppermost stratum (e.g., for the 0 $200 \mathrm{~m}$ net haul example, it would be the $0-100 \mathrm{~m}$ stratum).

Acoustic surveys-Two acoustic surveys were carried out across the Scotia Sea aboard the R/V vessel James Clark Ross (Fig. 1). In 2003, the survey was run from west to east, consisted of eight transects, and covered day and night hours (Klevjer et al. 2010). In 2008, five 24-h grids and two 12-h grids were run along one south-north transect. Volume backscattering strength (Sverdrup $\left[\mathrm{S}_{\mathrm{v}}\right]$, in decibels above a reference level of $1 \mu \mathrm{Pa} \mathrm{m}^{-1}$ [dB re $\left.1 \mathrm{~m}^{-1}\right]$ ) was collected using a scientific echo sounder (Simrad EK60) with hull-mounted split-beam $38-$ and $120-\mathrm{kHz}$ transducers. Krill were reliably detected at 6 to maximal $300 \mathrm{~m}$ from the transducer face. A swarm detection algorithm was applied to the $120-\mathrm{kHz}$ echogram data using Sonardata Echoview 4.0 "school detection module," which employs a shoal analysis and patch estimation system algorithm (Coetzee 2000). The applied swarm shape parameters are described in Klevjer et al. (2010). Swarms were positively identified as krill using the variable $\Delta \mathrm{S}_{\mathrm{v} 120-38} \mathrm{~dB}$ window identification technique (CCAMLR 2010). Krill biomass was expressed as acoustic biomass (area backscattering coefficient $\left[\mathrm{s}_{\mathrm{a}}\right], \mathrm{m}^{2} \mathrm{~m}^{-2}$ ). Further details on swarm detection and post-processing are given in Klevjer et al. (2010).

The nearest distance between cruise locations and land was computed using a great circle algorithm implemented in the R package (Ihaka and Gentleman 1996). Full vertical profiles of temperature and fluorescence were measured using a conductivity (C)-temperature (T)-depth (D) instrument (Sea-Bird' 911plus CTD). There were 64 hydrographic stations along the cruise track in 2003, and 3 to 5 hydrographic stations for each of the seven acoustic grid areas in 2008 .

Krill diet - Postlarval krill were sampled at 69 stations in the Scotia Sea and neighboring Bransfield Strait (Fig. 1) during various cruises of RRS James Clark Ross and krill fisheries vessels (January-February 2002, 2003, 2005, 2006; March 2004; April 2007; June-August 2004; July-August 2005, 2006; and November 2006). The krill were caught with target net tows in the top $200 \mathrm{~m}$ and immediately deep-frozen $\left(-80^{\circ} \mathrm{C}\right.$ on $\mathrm{R} / \mathrm{V}$ vessel James Clark Ross, $-20^{\circ} \mathrm{C}$ on fishery vessels).

Microscopic analysis of the stomach content was carried out on two to three individual krill per station. The stomach was dissected from frozen krill and the content emptied into a 4-mL water sample. The sample was gently mixed, transferred into an Utermöhl counting receptacle, 


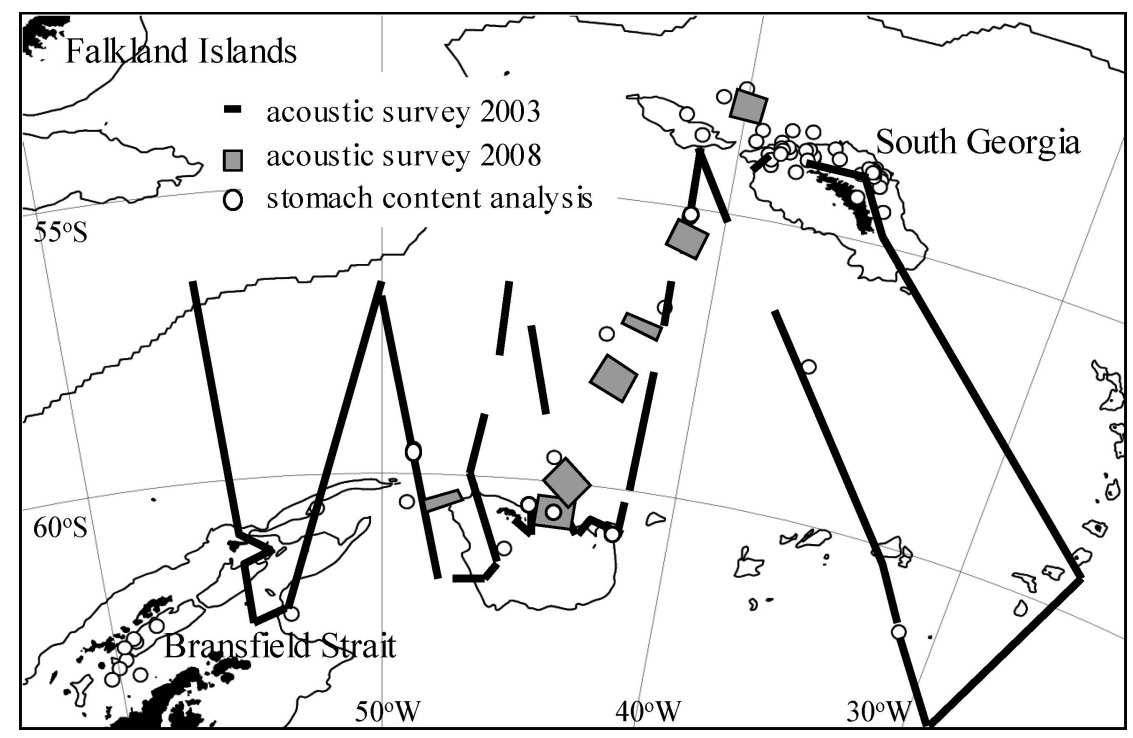

Fig. 1. Scotia Sea and Bransfield Strait; acoustic krill survey in January-February 2003 (solid black lines); acoustic krill survey in January-February 2008 (gray boxes); sampling stations for krill stomach content analysis, multiple cruises (white dots).

and settled for $\sim 2$ h. Rare items (e.g., copepod mandibles and tintinnids) were counted by scanning the complete receptacle at $\times 200$ magnification, while common items were enumerated from two perpendicular transects across the whole diameter of the receptacle. The dimensions of different food items were measured and their volume calculated as in Schmidt et al. (2006). For copepods, the width of the mandible blade was converted into prosome length (Karlson and Båmstedt 1994) and then into body volume (Mauchline 1998).

Fatty acid analysis and counts of lithogenic particles were carried out on one to two samples per station. For each of these samples, 10 frozen krill were dissected and stomach content emptied into a $1-\mathrm{mL}$ water sample. This pooled sample was freeze-dried, and lipids were extracted in chloroform: methanol $(2: 1, \mathrm{v}: \mathrm{v})$. A known amount of an internal standard $(23: 0)$ was added to each sample. Thereafter, dissolved lipids and remaining structural parts of the stomach content (including lithogenic particles) were separated by cold centrifugation (1500 revolutions per minute) in a tapered vial. From the supernatant, fatty acid methyl esters were generated by transesterification of lipid samples with $1 \%$ sulphuric acid in methanol (Christie 1982). Thin layer chromatography in a hexane: diethyl ether:acetic acid solvent system was used to purify the samples before analyzing with a Thermo Finnigan Trace 2000 gas chromatograph. Further details are given in Schmidt et al. (2006).

The nonlipid part of the stomach content was retained in the pellet of the centrifuged sample. Lithogenic particles were extracted from these samples by combusting all organic matter in a furnace $\left(550^{\circ} \mathrm{C}, 12 \mathrm{~h}\right)$. Second, biogenic silica was removed by exposing each sample to $2 \mathrm{~mL}$ of hot $1.5 \mathrm{~mol} \mathrm{~L}-1 \mathrm{NaOH}$ using a heating block at $100^{\circ} \mathrm{C}$ for $30 \mathrm{~min}$. At intervals, the samples were mixed, and the reaction was terminated with a few drops of $6 \mathrm{~mol} \mathrm{~L}^{-1}$ HCL. After the samples had settled and cooled, the supernatant was replaced by $4 \mathrm{~mL}$ of water and the vial was stored in the fridge. For microscopic analysis, the original sample or appropriate dilutions thereof were whirly-mixed, transferred into an Utermöhl counting receptacle, and settled for $\sim 2 \mathrm{~h}$. Lithogenic particles were counted in four size classes $(2-5 \mu \mathrm{m}, 5-10 \mu \mathrm{m}, 10-15 \mu \mathrm{m}$, and $15-25 \mu \mathrm{m})$ at $\times 200$ magnification.

Trace metal analysis of krill stomach content and muscle tissue-Iron concentrations in krill stomach and muscle were analyzed from 12 stations in the Scotia Sea (January-February 2002, 2003; March 2004). Inside a class 100 laminar flow cabinet, deep-frozen krill were briefly washed in ammonium acetate buffer $\left(\mathrm{NH}_{4} \mathrm{Ac}, 2 \mathrm{~mol} \mathrm{~L}-1\right.$, $\mathrm{pH} 4.5$ ) to remove attached trace metals. A ceramic scalpel and Teflon forceps were used to dissect the stomach content and separate the muscle of the 3rd abdominal segment from the remaining body. For each station, samples of 10-12 krill were pooled, freeze-dried, and weighed. To estimate the "labile" iron fraction, stomach content and muscle samples were exposed to $2 \mathrm{~mL} \mathrm{NH}_{4} \mathrm{Ac}$ buffer $\left(2 \mathrm{~mol} \mathrm{~L}^{-1}, \mathrm{pH} 4.5\right)$ for $2 \mathrm{~h}$ and then centrifuged; the leachate was analyzed with an inductively coupled plasma mass spectrometer (ICP-MS). The residues were transferred into Teflon tubes; and a mixture of $3 \mathrm{~mL}$ concentrated hydrochloric acid (HCL, trace metal grade), $3 \mathrm{~mL}$ concentrated nitric acid $\left(\mathrm{HNO}_{3}\right.$, trace metal grade), and $2.5 \mathrm{~mL}$ concentrated hydrofluoric acid (HF, ROMIL SpA grade) was added. Digestion was carried out in a microwave oven at $175^{\circ} \mathrm{C}$ for $60 \mathrm{~min}$. The digests were transferred to $30-\mathrm{mL}$ Teflon digestion pots with three rinses of $2 \%(\mathrm{v}: \mathrm{v}) \mathrm{HNO}_{3}$. These samples were dried overnight on a hot plate $\left(140^{\circ} \mathrm{C}\right)$ until $1 \mathrm{~mL}$ of liquid remained in the pots. To drive off fluorides, $0.25 \mathrm{~mL}$ of concentrated perchloric acid $\left(\mathrm{HClO}_{4}\right.$, ROMIL Ltd. SpA grade) was added, and the samples were evaporated on a hot plate at $140^{\circ} \mathrm{C}$. A further $0.25 \mathrm{~mL}$ of $\mathrm{HClO}_{4}$ was added when only a drop of liquid remained, 
Table 1. Euphausia superba, compilation of studies describing krill-seabed interactions. Observations are divided into four general methods: a) direct photographic observation of krill at the seabed by remotely operated vehicle, towed camera, or camera attached to gentoo penguins; b) sampling of krill at the seabed via epibenthic sledge, box corer, or light trap; c) krill in diet of benthic fish, starfish, or penguins foraging at the seabed; d) direct observation of krill feeding at the seabed or of seabed-derived food items in their stomachs. The table includes only studies where Euphausia superba was clearly identified. Unpublished images (pers. comm.) were checked for positive identification by one of the authors (A.A.).

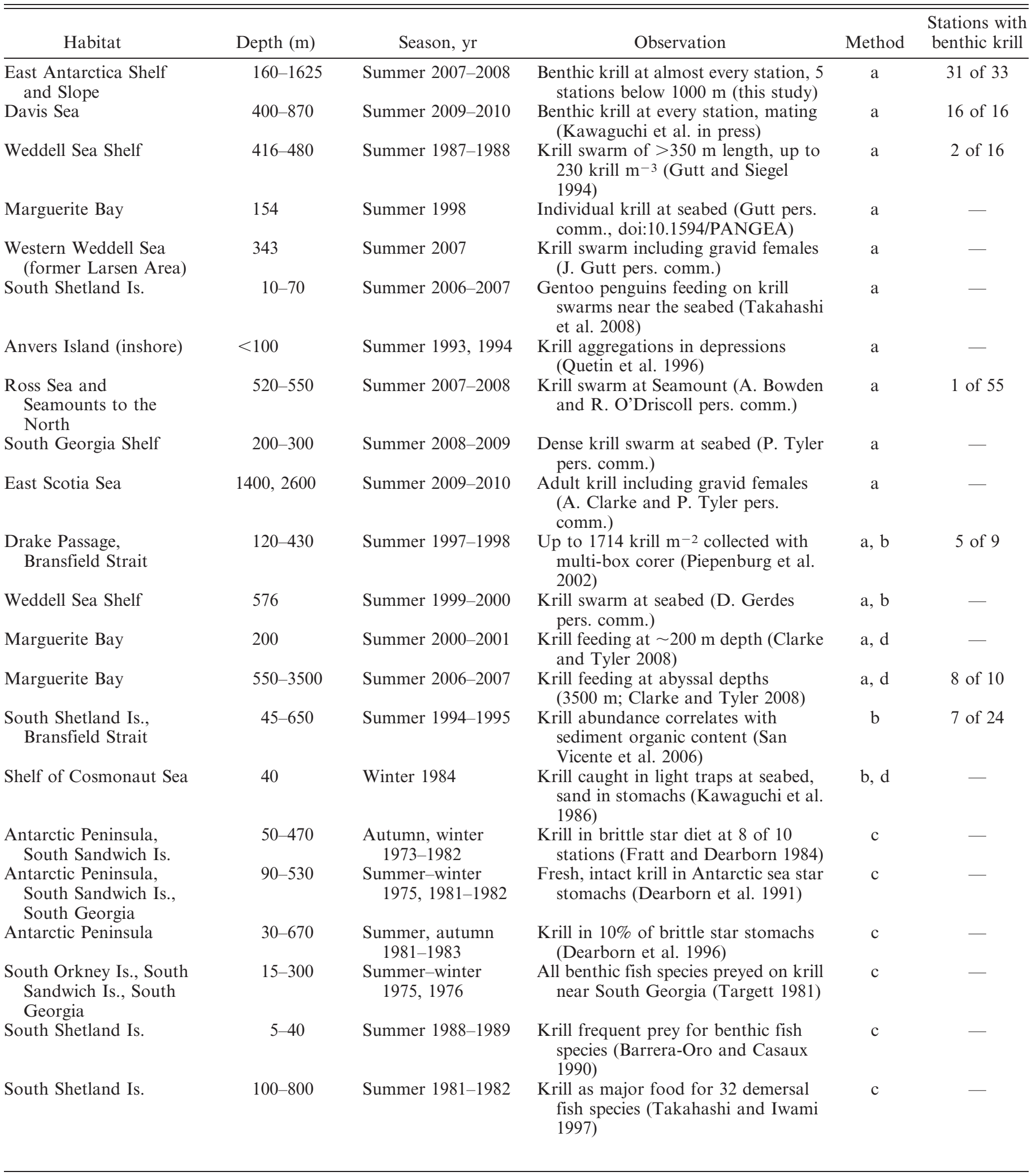


Table 1. Continued.

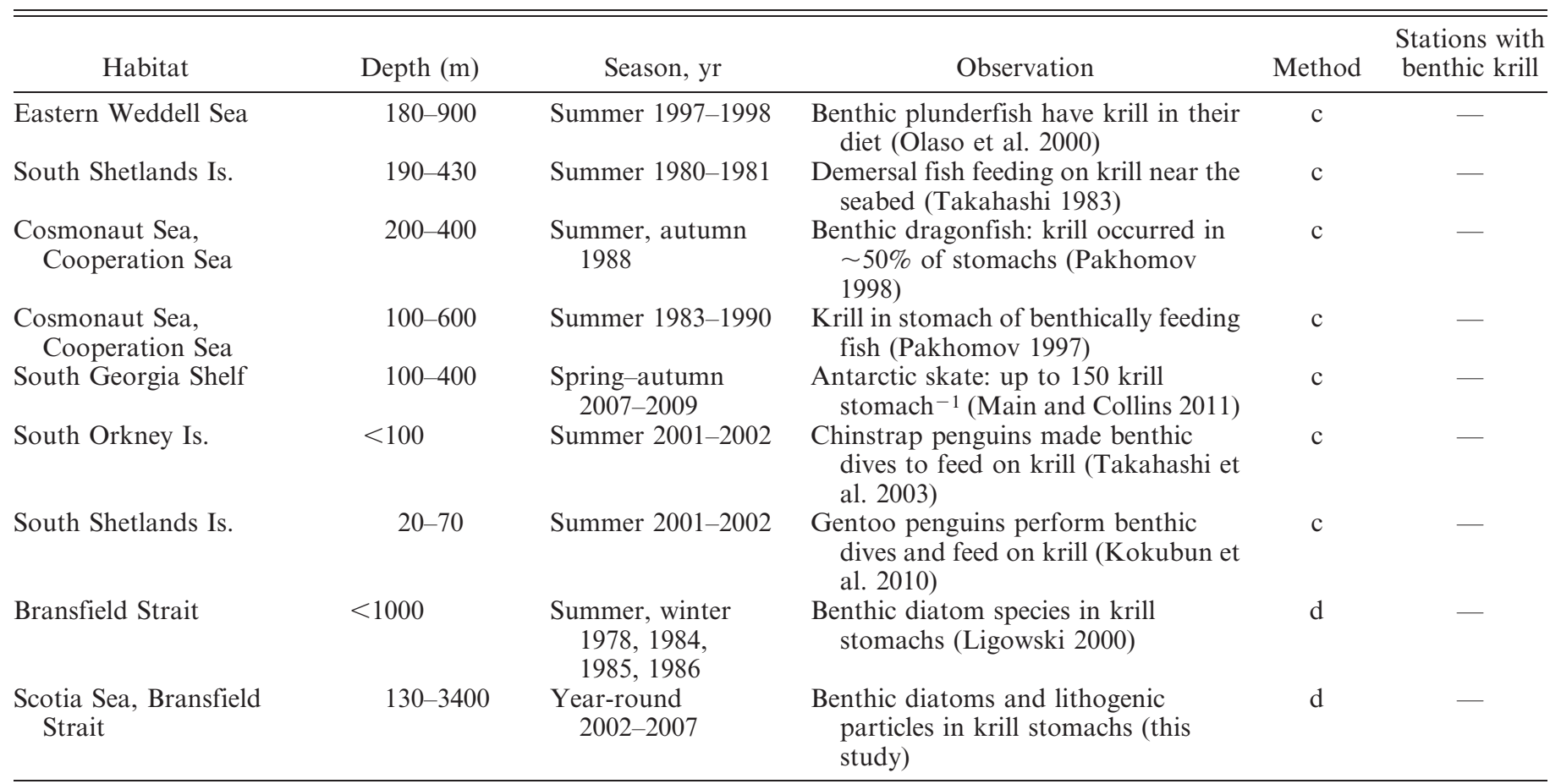

and the evaporation continued at $170^{\circ} \mathrm{C}$ to complete dryness. The samples were redissolved in a known amount of $2 \% \mathrm{HNO}_{3}$ to form the mother solutions, which were analyzed on an ICP-MS for "refractory" iron. To verify the effectiveness of the digestion procedure, samples of a certified standard reference material from the National Institute of Standards and Technology (NIST 1648a, urban particulate material) and an uncertified, but well-characterized reference material of loess sediment were digested at the same time as the samples.

\section{Results}

Compilation of benthic observations of krill-To our knowledge there are 14 studies that have directly observed E. superba at the seabed, many of them yet unpublished (Table 1). During other video surveys, e.g., within the project Food for Benthos on the Antarctic Continental Shelf (FOODBANCS), shrimp-like organisms (possibly including $E$. superba) were regularly seen at the benthos, but were not identified to species level (P. Sumida pers. comm.). Most of the studies presented in Table 1 were conducted over the shelf (10-500 m water depth), but krill were found on all of the 10 stations deeper than $1000 \mathrm{~m}$, which suggests that their benthic migrations are not restricted to shallow waters. Numbers of krill observed at the seabed varied from a few individuals to dense swarms (Table 1).

Further evidence for krill migrations to the seabed comes from epibenthic sampling, diet analysis of benthic predators, and the examination of krill stomach content (Table 1). Mapping of the study locations (Fig. 2) and seasons (Table 1) shows that krill-seabed interactions are not restricted to winter (Kawaguchi et al. 1986) or areas with elevated seabed temperature (Clarke and Tyler 2008), but are circumpolar in extent and occur year-round. Krill were found at 70 out of 164 stations where their appearance at the seabed was systematically recorded (Table 1). This encounter rate is high, considering that epipelagic nets caught krill in only $76 \%$ (shelf, $n=2859$ ) or $61 \%$ (ocean, $n$ $=4599$ ) of all hauls (Atkinson et al. 2008).

Photographic survey of euphausiids at the seabed-We used a survey off Terre Adélie in the Indian sector of the Southern Ocean for an inspection of benthic images for krill. Out of the 2408 analyzed images, 415 showed euphausiids $(\sim 17 \%)$. E. superba were clearly identified in several images, while in others low resolution prevented their separation from Euphausia crystallorophias, which might co-occur in this area (Nicol et al. 2000). Most images with euphausiids showed a few individuals rather than large abundances, but a precise count was often impossible. Out of the 33 sampling stations, euphausiids were sighted at the benthos in 31 . The encounter rate per station ranged from 0-61\% of all images (Fig. 3). Considering the patchy distribution of krill in the water column (Atkinson et al. 2008), these encounter rates seem high and suggest that migration of euphausiids to the seabed is widespread and frequent within this sampling area.

As a second step, we tried to identify some of the environmental parameters that may have initiated the benthic interactions. None of the following were clear predictors of euphausiid encounter rate at the seabed: surface water chlorophyll $a$ (Chl $a$ ) concentration, seabed 


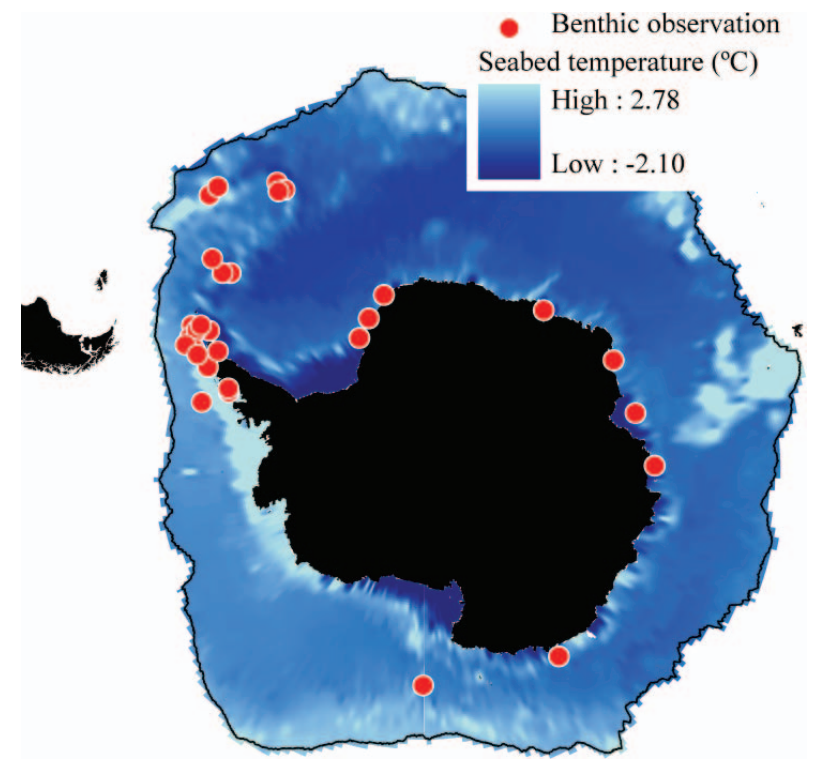

Fig. 2. Euphausia superba, circumpolar records of benthic observations. Each dot represents one study (details in Table 1). Seabed temperatures are taken from Clarke et al. (2009).

coverage with biota, seabed substratum, and water depth. The only parameter showing a significant effect was the time of day $\left(R^{2}=0.188, p=0.009, n=33\right)$, with slightly higher encounter rates in the early morning (around 04:00 h local time) compared to evening or night.

Vertical distribution of krill in the water columnNet samples: Our first approach to study the vertical distribution of postlarval krill is based on 8544 net catches compiled in the krillbase database. Two aspects were considered, krill density (individuals $\mathrm{m}^{-3}$ ) and the likelihood of their encounter (number of nets containing krill as percentage of total net samples). While krill densities are 12 orders of magnitude higher in the upper $200 \mathrm{~m}$ water column than at depth (Fig. 4; Table 2), the likelihood of capturing krill is not greatly dissimilar: Krill were present in $64 \%$ of all hauls from the upper $200 \mathrm{~m}$ of the water column $(n=8133)$ and in $48 \%$ of hauls that sampled only the water column below $200 \mathrm{~m}$ depth $(n=411)$. Combined, these results suggest that even though krill densities are low in deeper waters, the encounter of small numbers is common.

Moreover, krill densities below $200 \mathrm{~m}$ depth extend in relatively consistent amounts throughout the water column. Thus, krill caught at depth are not simply scattered from an epipelagic population center, but reflect deep penetration into the ocean, possibly even transit to the seabed. When calculating the total krill abundance over the sampled water column (individuals $\mathrm{m}^{-2}$ ), the low krill densities at depth translate into relatively high total numbers (Table 2). This is because the sampled habitat volume below $200 \mathrm{~m}$ was twice (shelf) or even nine times (ocean) as large as the epipelagic layer. Therefore, based on data in Table 2, 20.3\% of the sampled oceanic krill population and $8.5 \%$ of the shelf population were found below $200 \mathrm{~m}$. These percentages would even increase if significant amounts of krill were below the bottom sampling depth of the net or directly at the seabed.

Acoustic surveys: Our second approach to study the vertical distribution of krill is based on two acoustic surveys in the Scotia Sea in January 2003 and January 2008. Compared to net sampling, acoustics provides much higher vertical resolution and spatial coverage. A total of 22,400 krill swarms were analyzed. However, acoustic

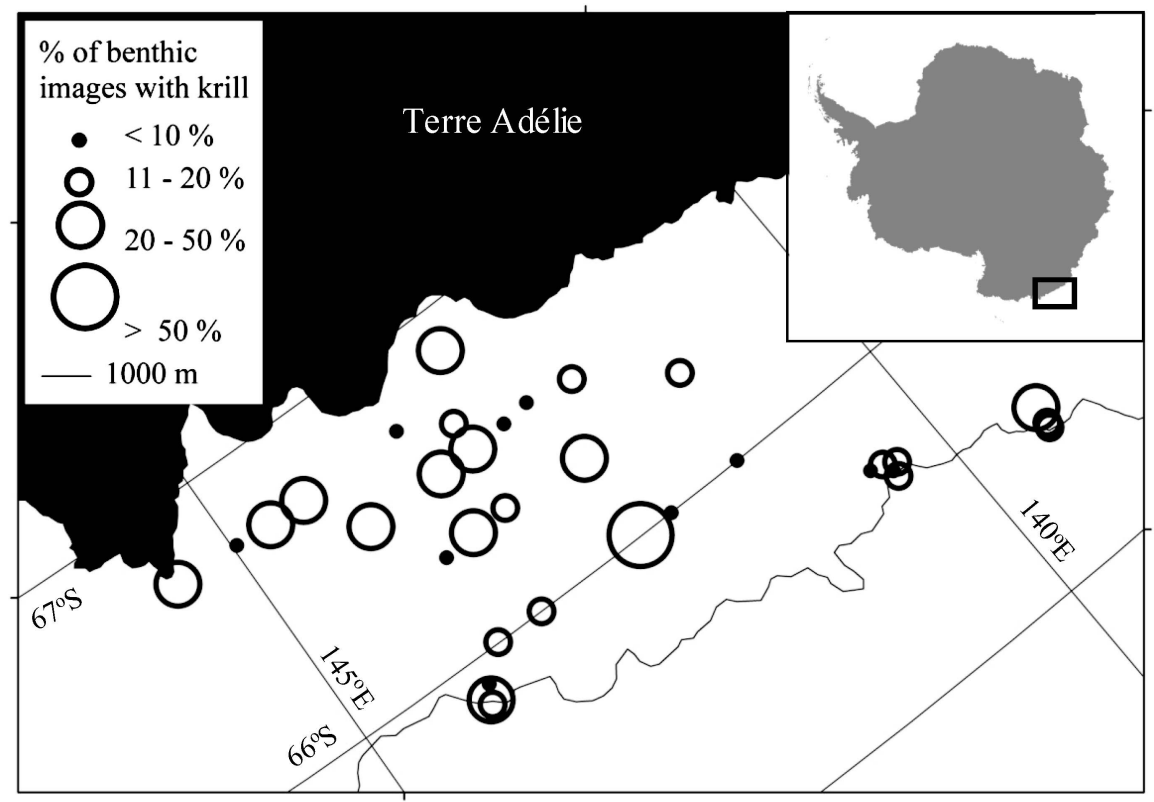

Fig. 3. Euphausia superba, photographic survey at the seabed off Terre Adélie. The size of the circles relates to the krill encounter rate (number of images with krill vs. total number of images). 


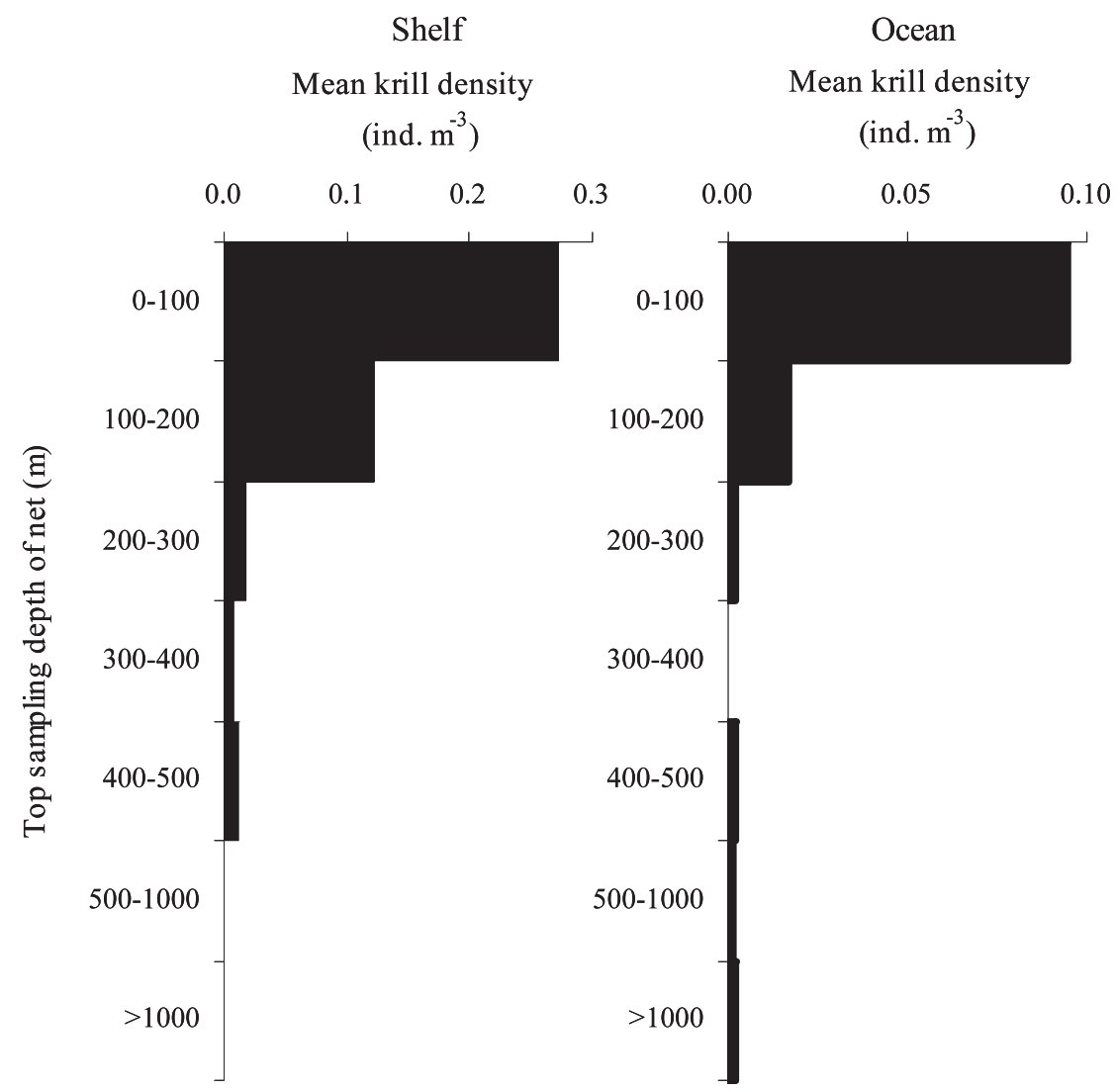

Fig. 4. Euphausia superba, vertical distribution of krill densities (ind. $\mathrm{m}^{-3}$ ). The plots are based on 8544 net hauls from various cruises compiled in the "krillbase" database.

signals progressively attenuate with distance from the transducer, which limited the reliable detection of krill swarms to the upper $250-300 \mathrm{~m}$ of the water column.

Acoustic biomass and number of swarms peaked between 20 and $40 \mathrm{~m}$ depth (Fig. 5). However, in common with previous findings (Demer and Hewitt 1995; Demer 2004), small but consistent amounts of krill extended from $\sim 150 \mathrm{~m}$ right down to the detection limit at $300 \mathrm{~m}$ (Fig. 5). To explain this occurrence of krill swarms well below the population center, three factors were considered: food availability, predator avoidance, and transit to greater depths. Simultaneously sampled phytoplankton concentrations (fluorescence) showed a peak in the upper 30-m water column (Fig. 5), and deepest phytoplankton maxima were at $\sim 100 \mathrm{~m}$. Mesopelagic krill predators such as fish and squid cannot be avoided by migrating into their main habitat, while foraging dives of air-breathing predators only reach to a maximum depth of $\sim 200 \mathrm{~m}$ in summer (Fig. 5). Thus, neither food availability nor avoidance of predators can easily explain the presence of krill swarms as deep as $300 \mathrm{~m}$. However, the average size of krill swarms decreased with depth (Fig. 6), which is characteristic for vertical migration. According to acoustic studies by Zhou and Dorland (2004), E. superba form small irregular aggregation shapes during vertical migration, which can reorganize to bigger swarms when the migration terminates.
Thus, results from both acoustics and net sampling show that, with sufficiently large data sets, evidence for deep vertical migration of krill can be found. The results in Figs. 4 and 5 suggest that similar amounts of krill are distributed throughout the deep-water column, which allows us to estimate a potential krill biomass between $200 \mathrm{~m}$ water depth and the seabed. For this calculation, we used the average acoustic krill biomass estimated for the 200-300 m depth stratum, which accounted for $0.7 \%$ of the total biomass in the top $300 \mathrm{~m}$. This small proportion of deep krill would add up to $2 \%$ of the total biomass over $500 \mathrm{~m}$ and $\sim 11 \%$ over $2000 \mathrm{~m}$. However, the value of $0.7 \%$ is a conservative estimate due to attenuation of acoustic signals, which will affect the detection of small krill swarms at depth more than large surface swarms. This might explain why percentages of deep krill based on acoustic estimates are somewhat lower than net-based estimates at $500 \mathrm{~m}$ and $2000 \mathrm{~m}$ (Table 2).

Differences in krill vertical distribution with distance from land-The vertical distribution of krill is not a fixed feature, but can vary with local conditions (Klevjer et al. 2010). Based on the acoustic data sets, we found that in areas close to land the proportions of krill biomass in the deepest analyzed stratum (200-300 m depth) were relatively high, but an order of magnitude lower at moderate distances from land (Table 3). Beyond $200 \mathrm{~km}$ offshore, 
Table 2. Euphausia superba, number of individuals within seven depth strata, presented for oceanic and shelf waters. Numbers of krill $\mathrm{m}^{-2}$ were calculated from krill densities (individuals [ind.] $\mathrm{m}^{-3}$ ) multiplied by the vertical interval of the respective stratum. For the $>1000 \mathrm{~m}$ stratum in the oceanic water, the mean vertical interval of net hauls sampling just this stratum was $952 \mathrm{~m}$.

\begin{tabular}{|c|c|c|c|c|c|c|c|}
\hline \multirow[b]{2}{*}{$\begin{array}{l}\text { Top sampling } \\
\text { depth of net (m) }\end{array}$} & \multirow[b]{2}{*}{$\begin{array}{c}\text { Vertical } \\
\text { interval }(\mathrm{m})\end{array}$} & \multicolumn{3}{|c|}{ Oceanic hauls } & \multicolumn{3}{|c|}{ Shelf hauls } \\
\hline & & $\begin{array}{l}\text { No. of } \\
\text { hauls }\end{array}$ & $\begin{array}{l}\text { Krill density } \\
\text { (ind. } \mathrm{m}^{-3} \text { ) }\end{array}$ & $\begin{array}{l}\text { Krill No. } \\
\text { (ind. } \mathrm{m}^{-2} \text { ) }\end{array}$ & $\begin{array}{l}\text { No. of } \\
\text { hauls }\end{array}$ & $\begin{array}{l}\text { Krill density } \\
\text { (ind. } \mathrm{m}^{-3} \text { ) }\end{array}$ & $\begin{array}{l}\text { Krill No. } \\
\text { (ind. } \mathrm{m}^{-2} \text { ) }\end{array}$ \\
\hline $100-200$ & 100 & 179 & 0.017 & 1.7 & 134 & 0.123 & 12.3 \\
\hline $200-300$ & 100 & 177 & 0.0017 & 0.17 & 56 & 0.0173 & 1.73 \\
\hline $300-400$ & 100 & 18 & 0.00014 & 0.014 & 7 & 0.00832 & 0.832 \\
\hline$>1000$ & 952 & 14 & 0.0019 & 1.777 & - & - & - \\
\hline \multirow{2}{*}{\multicolumn{2}{|c|}{$\begin{array}{l}\text { Total krill No. (ind. } \mathrm{m}^{-2} \text { ): } \\
\text { Population below } 200 \mathrm{~m}^{(\%)} \text { : }\end{array}$}} & & & 13.96 & & & 43.32 \\
\hline & & & & 20.3 & & & 8.5 \\
\hline
\end{tabular}

the fraction of deep krill increased again. This pattern was the same for both of our acoustic surveys (2003 and 2008), which suggests that it reflects true regional differences in krill vertical distribution rather than random observations. Biotic factors that also change with distance from land in the Scotia Sea in summer are the phytoplankton availability and the predation pressure from land-breeding predators (Table 3). Both predation risk and feeding reward increase towards land, but they seem to change at different scales. While the predation rate sharply decreases beyond $\sim 100 \mathrm{~km}$ from the colony (Murphy 1995; Atkinson et al. 2008), moderate to high food availability can extend over $200 \mathrm{~km}$ from land (Table 3; Atkinson et al. 2008).

Fatty acid and microscopic analyses of krill stomach content-The krill used for stomach content analysis were caught from the upper 200-m water column of 69 stations in the Scotia Sea and Bransfield Strait and were sampled during different seasons and years. In accordance with the aim of the study to investigate krill-seabed interactions, we

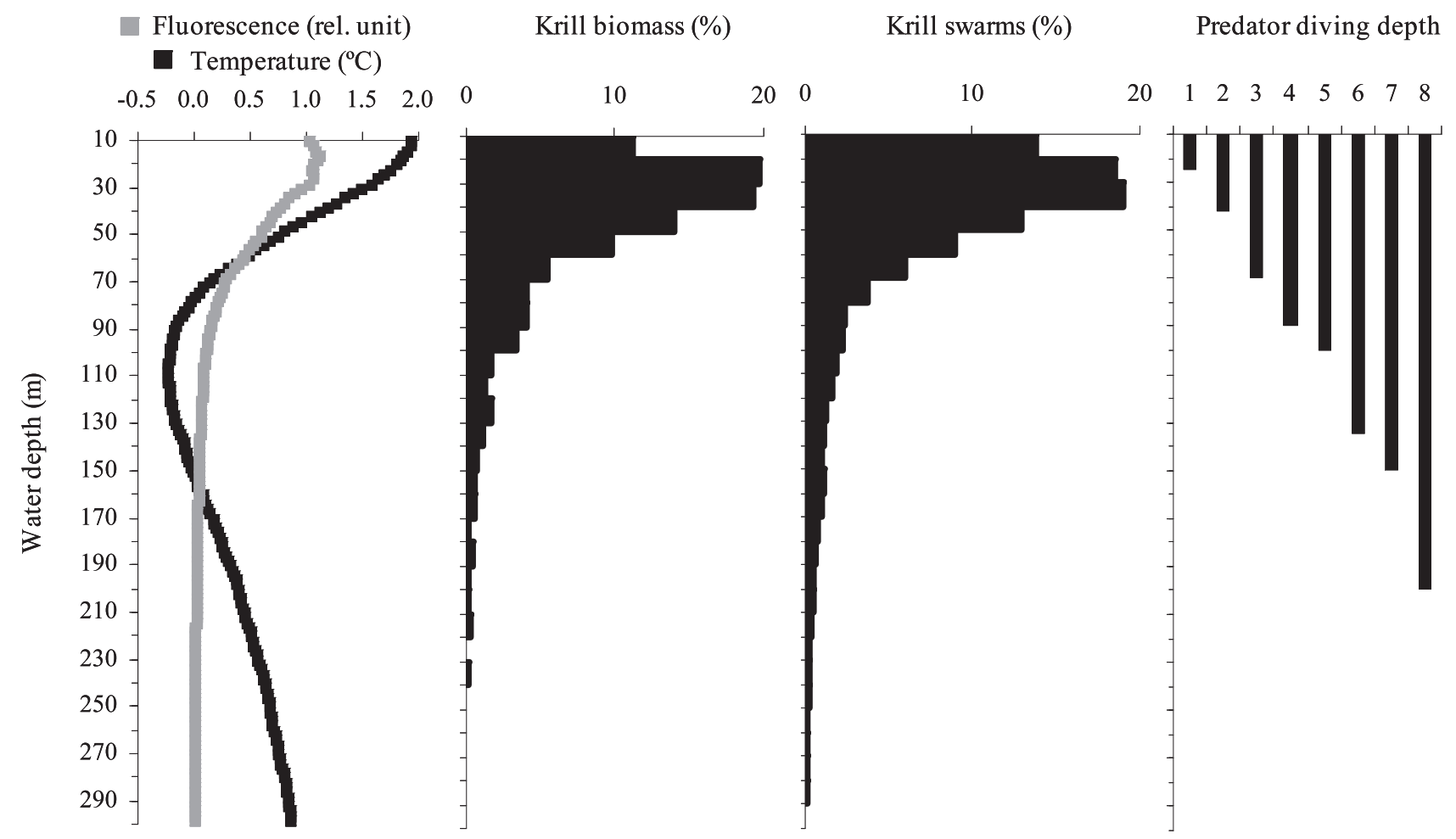

Fig. 5. Euphausia superba, vertical distribution of acoustic biomass and swarm frequency (Scotia Sea, January-February 2003 and 2008, $n=22,400$ ), co-occurring hydrography (phytoplankton biomass and temperature, $n=88$ ), and mean maximum depth of foraging dives of air-breathing krill predators. 1-diving petrel (Prince and Jones 1992), 2-Macaroni penguin (Green et al. 2005), 3-Gentoo penguin (Takahashi et al. 2008), 4-Adélie penguin (Kato et al. 2009), 5-Chinstrap penguin (Takahashi et al. 2003), 6-Antarctic fur seal (Staniland et al. 2004), 7-Crabeater seal (Burns et al. 2004), 8-Baleen whales (Shirihai 2002). (rel. unit—relative unit.) 


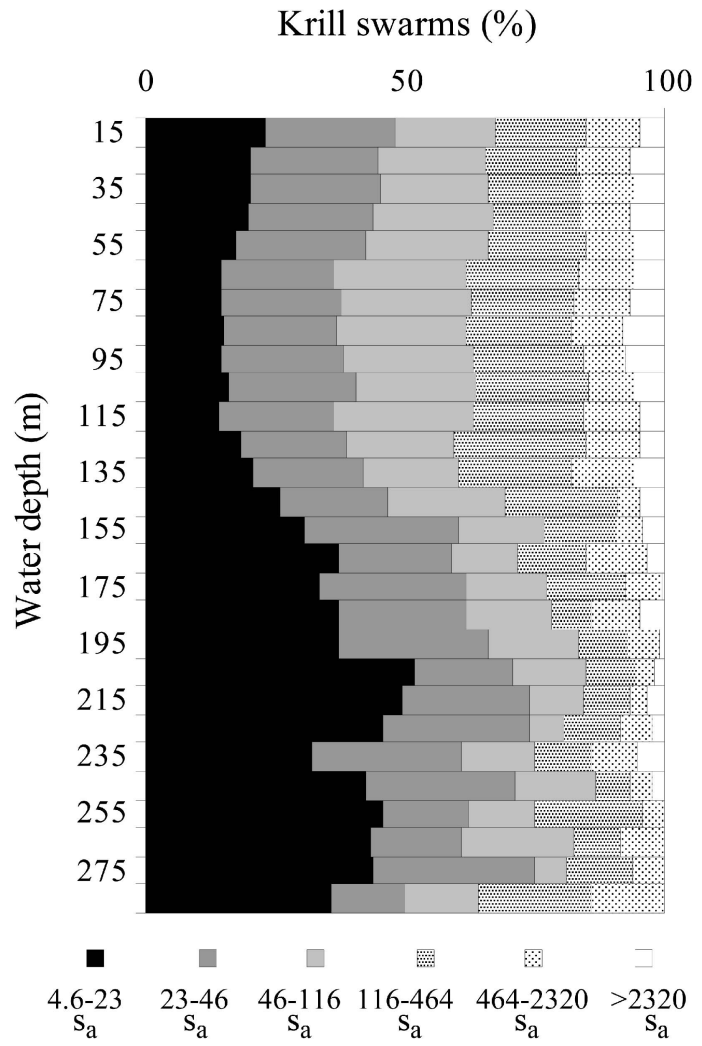

Fig. 6. Euphausia superba, vertical distribution of krill swarm sizes $(n=22,400)$. Area backscattering coefficient, $s_{a}(\times$ $\left.10^{-8} \mathrm{~m}^{2} \mathrm{~m}^{-2}\right)$ indicates the acoustic biomass of a krill swarm.

paid special attention to a quantitative estimate of the number and size of lithogenic particles in krill stomachs and their co-occurrence with various food items.

The data show a large range in the particle number per stomach, but high values were found throughout the year (Fig. 7). For krill sampled at four stations in a bay near Neumayer Glacier (South Georgia), these lithogenic particles co-occurred with fatty acids typical for fresh phytoplankton (16:4[n-1]; 18:4[n-3]; Fig. 8A). However, at the remaining 65 stations further from land, lithogenic particles co-occurred with fatty acid indicators of phytodetritus (18:1[n-7]/16:4[n-1]; 18:1[n-7]/16:1[n-7]; 18:2[n-6]) and bacteria (iso+anteiso 17:0; 18:1[n-7]; Fig. 8B) or a mixture of phytodetritus and copepods (20:1 and 22:1 isomers; Fig. 8C). In the otherwise iron-limited Southern Ocean, lithogenic particles in surface waters are usually associated with iron fertilization and high phytoplankton concentrations (Smith et al. 2007; Korb et al. 2008). This suggests that the co-occurrence of lithogenic particles with high amounts of fresh phytoplankton in krill stomachs indicates their uptake in surface water (Fig. 8A). Conversely, if lithogenic particles did not co-occur with fresh phytoplankton in krill stomachs but instead with phytodetritus, krill might have fed at the seabed (Fig. 8B,C).

This general association between lithogenic particles and phytodetritus or copepods in krill stomachs is confirmed by microscopic examinations. The suite of items likely found at the seabed (benthic diatoms and fragmented pelagic diatoms) is positively related to lithogenic particles (Fig. 9A), whereas those encountered near the surface (e.g., intact pelagic diatoms and dinoflagellates) are negatively related to the number of lithogenic particles (Fig. 9B). Surprising is the co-occurrence of lithogenic particles with copepod mandibles in krill stomachs (Fig. 9A), as copepods inhabit mainly the upper water column.

However, several copepod species are known to diapause for up to 8-9 months in deeper water in the southern Scotia Sea (Atkinson et al. 1997), and krill searching individually near the seabed might be more likely to encounter and capture copepods than those feeding in great swarms in surface water.

Co-occurrence of lithogenic particles and iron in krill stomachs - We observed that stomach samples with a high load of lithogenic particles turned ochre during combustion, suggesting the presence of Fe-oxides (Fig. 10A). Subsequent trace metal analysis confirmed that high amounts of refractory and labile iron in krill stomachs co-occur with the uptake of lithogenic particles (Fig. 10B), but not with the ingestion of fresh food items (Fig. 10C). As previously established, high amounts of lithogenic particles in krill stomachs indicate benthic feeding, and therefore the iron

Table 3. Euphausia superba. Changes in phytoplankton availability, effect from land-based air-breathing predators, and vertical migration of krill with distance from land, during austral summer. The acoustic krill biomass (area backscattering coefficient, $\mathrm{s}_{\mathrm{a}}$ ) in the $200-300 \mathrm{~m}$ stratum, expressed as percentage of the total krill biomass between 10 and $300 \mathrm{~m}$, is used as an indicator of krill migration into deeper water. Maximum fluorescence indicates the available phytoplankton biomass. Krill consumption rates are given in Murphy (1995) and Atkinson et al. (2008).

\begin{tabular}{lccc}
\hline \hline & \multicolumn{2}{c}{ Distance from land $(\mathrm{km})$} \\
\cline { 2 - 4 } & $10-50$ & $50-200$ & $200-400$ \\
\hline Deep krill biomass (\% of total $\mathrm{s}_{\mathrm{a}}$ ) & & & \\
$\quad 2003$ & 0.6 & 0.03 & 0.3 \\
$\quad 2008$ & 0.9 & 0.07 & 4.3 \\
Maximum Chl $a$ fluorescence (relative unit) & & & 0.88 \\
2003 & 2.18 & 0.90 & 0.39 \\
2008 & 0.62 & Transitional & Low \\
Krill consumption by air-breathing predators & High & &
\end{tabular}




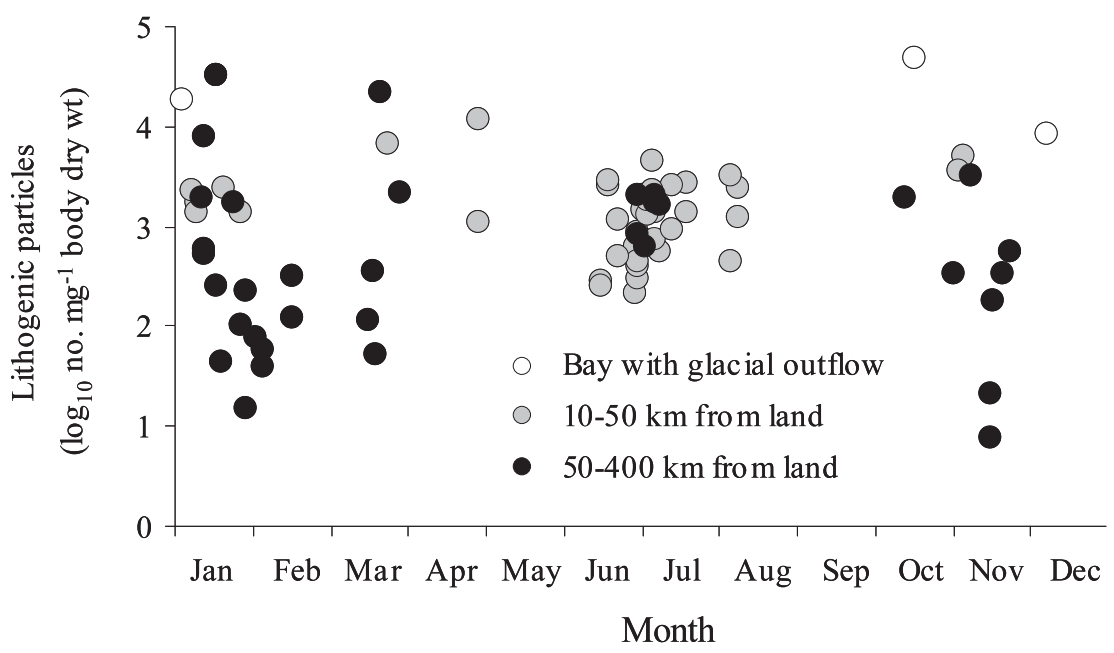

Fig. 7. Euphausia superba, stomach content of lithogenic particles in relation to time of the year. Krill were sampled in the Scotia Sea and Bransfield Strait during multiple cruises.

would be newly introduced to surface water upon their return from the deep ocean. Some of the iron ingested at the seabed was most likely of biogenic origin as suggested by the enhanced proportion of labile iron (4-5\%) and relatively high Fe:Al ratios (0.7-0.9; Planquette et al. 2009). The significance of this Fe uptake is illustrated by the fact that, in concert with benthic feeding, iron concentrations can be $>$ 1000 times higher in krill stomachs than in their muscle tissue (Fig. 10D). Converting these concentrations into absolute amounts, we found up to 12 times more iron in krill stomachs than in the whole of the remaining body.

\section{Discussion}

Where, when and why do krill visit the seabed? - Direct observations of krill at the seabed have underlined the close link between their benthic migrations and the uptake of food. Thus, Clarke and Tyler (2008) noted that whenever krill were detected at the seabed they were seen actively feeding, and there was a loose correlation between the concentration of benthic krill and the amount of phytodetritus at the seabed. This raises the question of why krill sometimes prefer feeding at the seabed rather than in their primary habitat, the upper water column.

To understand this behavior, three aspects have to be considered. First, feeding success near the surface can be low, e.g., due to food shortage or predator avoidance. In the Scotia Sea, such unfavorable surface conditions can occur close to land, where the effect from air-breathing predators is high, and far from land, where phytoplankton concentrations are relatively low even in summer (Table 3 ). In both zones, we found a larger part of the krill population in the deepest stratum of acoustic detection (200-300 m) compared to that found at intermediate distances from land, suggesting that under such conditions some krill migrated away from surface waters to feed at depth. At intermediate distance from land, predation risk is usually reduced, and moderate to high phytoplankton abundances favor a shallow krill distribution. However, more work is needed to determine the surface-layer factors that drive deep migrations and benthic feeding.

A second potentially relevant point is that, in contrast to the upper ocean, where food is often ephemeral, the seabed can act as a "food bank," with phytoplankton being accumulated, temporarily buried, and only slowly degraded (Smith et al. 2006). Studies on benthic deposit feeders have shown that high-quality organic matter can be available at the seabed even in winter (Smith and DeMaster 2008). Krill can efficiently use these food banks because they are adapted to feeding on surfaces (Hamner et al. 1983), and their high mobility gives an advantage in locating patchy food. Deep scattering layers of euphausiids, in close vicinity to the seabed, have been observed during winter (Kawaguchi and Nicol 2007).

The third aspect is that krill are strong swimmers (Hamner et al. 1983) with a cruising speed of $20 \mathrm{~cm} \mathrm{~s}^{-1}$ (Kils 1981), which would allow them to migrate $1000 \mathrm{~m}$ in $<2$ h. Huntley and Zhou (2004) found a strong relationship between body mass and swimming speed among pelagic organisms. Even euphausiid species much

Fig. 8. Euphausia superba, principal component analysis of fatty acids and co-occurring lithogenic particles in krill stomach content. The fatty acids indicate different food sources: fresh phytoplankton (green) i.e., diatoms (16:4[n-1]; 16:1[n-7]) and flagellates (18:4[n-3]); degrading material (brown) i.e., phytodetritus (18:1[n-7]/16:4[n-1]; 18:1[n-7]/16:1[n-7]), cell walls (18:2[n-6]), and bacteria (iso + anteiso17:0; 18:1[n-7]); heterotrophic food (magenta) i.e., copepods (20:1+22:1 isomers) and heterotrophs in general (18:1[n-9]/18:1[n-7]). Food items that align together on the PC1PC2 plane are considered to have been ingested at the same time and/or in the same habitat. (A) South Georgia, bay with glacial outflow $(n=4)$; (B) Scotia Sea, $10-50 \mathrm{~km}$ from land $(n=39)$; (C) Scotia Sea, $50-400 \mathrm{~km}$ from land $(n=35)$. The fraction of unconstrained variance accounted for by each axis is given in brackets. 

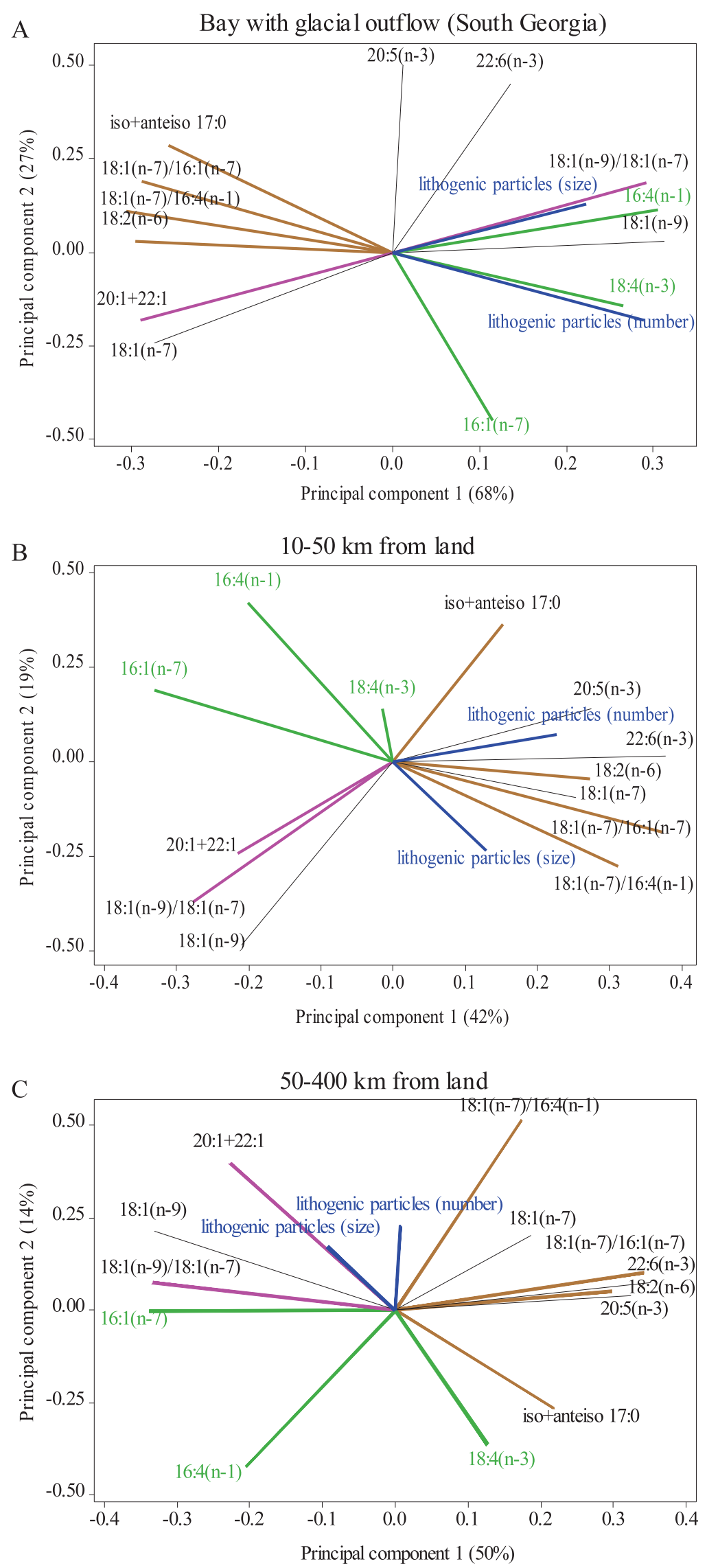
smaller than E. superba migrate vertically for 400-1000 m on a daily basis (Sardou et al. 1996; Antezana 2009). Thus, with a body length of up to $6.4 \mathrm{~cm}$ and wet weight of $2 \mathrm{~g}$, adult $E$. superba will have a substantial potential for vertical migrations.

We conclude that vertical feeding migrations by krill are flexible and may be induced by suboptimal feeding in surface water. Strong swimming abilities of adult krill and the presence of benthic food banks make the seabed an attractive and attainable alternative feeding ground.

Ecological relevance of benthic krill_-The first mention of E. superba interactions with the benthos was made $\sim 30 \mathrm{yr}$ ago (Targett 1981; Fratt and Dearborn 1984); and, since, individual krill and dense swarms have repeatedly been observed at the seabed (Gutt and Siegel 1994), from coastal areas (Kawaguchi et al. 1986) to abyssal depths (Clarke and Tyler 2008). However, the general perception remains that E. superba is an epipelagic species, with benthic krill being ecological outliers (Brierley 2008). This is because the proportion of krill found at the seabed is believed to be very small compared to that in the upper water column, and feeding at the seabed is thought to be of low energetic benefit, especially when combined with long-distance migrations.

Results of the present study challenge these arguments: First, we compiled $\sim 30$ studies linking krill to the seabed. The number of studies and frequency of encounter suggests that krill-seabed interactions are widespread. They can happen throughout the year and throughout their circumpolar range, including offshore habitats and areas with low seabed temperature. Within the last few years, the number of benthic camera surveys reporting krill or unidentified shrimp-like crustaceans potentially being krill has increased rapidly (Table 1; P. Sumida pers. comm.). Even their observation at abyssal depths has been replicated in a different area (Table 1; A. Clarke and P. Tyler pers. comm.), and a recent study has reported on krill mating near the seabed (Table 1; Kawaguchi et al. in press).

Second, we analyzed two large data sets on krill biomass distribution in the water column, one based on net samples, the other on acoustic surveys. Both showed independently that, even in summer, 2-20\% of the krill is below the top $200 \mathrm{~m}$ at any given time, and this does not include the fraction at or near the seabed. However, these percentages represent only average data, and proportions of deep krill can be much higher. Figure 11 illustrates an occasion when up to $75 \%$ of the krill population appeared as a benthic or midwater aggregation below $200 \mathrm{~m}$ water depth. Commercial fishery trawlers have found similar echograms of dense krill aggregations near the seabed (Kawaguchi and Nicol 2007). These results suggest that the part of the krill population involved in deep migrations is not minor. Restricting routine krill surveys for fishery and ecosystem management to the upper 200-m water column (Hewitt et al. 2004; Siegel 2005) will certainly underestimate the overall krill stock.

Third, the stomach content of krill caught in the upper water column shows that they use both surface- and seabed-derived foods on a dynamic basis, with phytodetritus, bacteria, and copepods ingested either in transit to or from benthic habitats or directly at the seabed. This suggests that benthic feeding is a true part of the versatile feeding ecology of krill. The energetic benefit of longdistance feeding migrations has to be seen against the potential alternative for being eaten or starving when remaining in surface water. Long-distance feeding migrations, to balance the trade-off between predation risks and gaining food, are not exceptional among micronekton. Off Hawaii, midwater fish and shrimp of similar size to krill perform daily offshore-onshore migrations of $2-11 \mathrm{~km}$ round-trip to feed (Benoit-Bird and Au 2006).

The krill found at depth are usually adult, including gravid females (Marin et al. 1991; Clarke and Tyler 2008; Taki et al. 2008). Benthic feeding grounds might be more accessible to larger, adult krill due to their higher swimming speed (Huntley and Zhou 2004), which offers a wider choice of habitat. Thus, each of the ontogenetic stages of $E$. superba has its specific way to acquire food while avoiding predators: Larvae dwell under winter sea-ice (Daly 1990), juveniles live in large swarms (Tarling et al. 2009), and adults additionally explore the benthos. Together these strategies might increase resource partitioning within the krill population and therefore contribute to the flexibility and overall success of Antarctic krill.

Implications for bentho-pelagic coupling - The benthic feeding migrations not only have implication for $E$. superba but also for the coupling of benthic and pelagic food webs. The regular appearance of krill in the stomachs of demersal fish and brittle stars indicates their role as a food source for benthic predators (Table 1), but quantitative assessments still await further studies. Thus, on their downward migration, krill contribute to the export of carbon and nutrients from surface water to the deep ocean, due to their excretion, defecation, and consumption by predators. On the other hand, the occurrence of lithogenic particles and benthos-derived food in stomachs of krill sampled in the upper 200-m water column (Fig. 8B,C) suggests that, on return from depth, krill also reintroduce benthic material into surface waters.

Comparing export vs. import, it might be assumed that vertical migration of krill will cause more export of carbon and nutrients out of the mixed layer than import back into this layer. This is because export is realized as soon as krill leave the relatively thin upper mixed layer; however, import requires their migration throughout the whole water column, and, therefore, prior evacuation of gut content is more likely. However, this assumption does not take into account that gut passage times of krill slow during periods of nonfeeding (Perissinotto and Pakhomov 1996) and that nutrient concentrations can be orders of magnitude higher in deeper water, and especially at the seabed, than in impoverished surface waters (Coale et al. 2005; Bruland and Lohan 2006; De La Rocha 2006). Thus, even if some gut content is lost during transit, benthic feeding by krill and their subsequent return to surface waters may lead to a net upward flux of certain nutrients or trace metals.

Implications for the vertical transfer of iron-The release of dissolved iron by krill after benthic feeding has not 
A
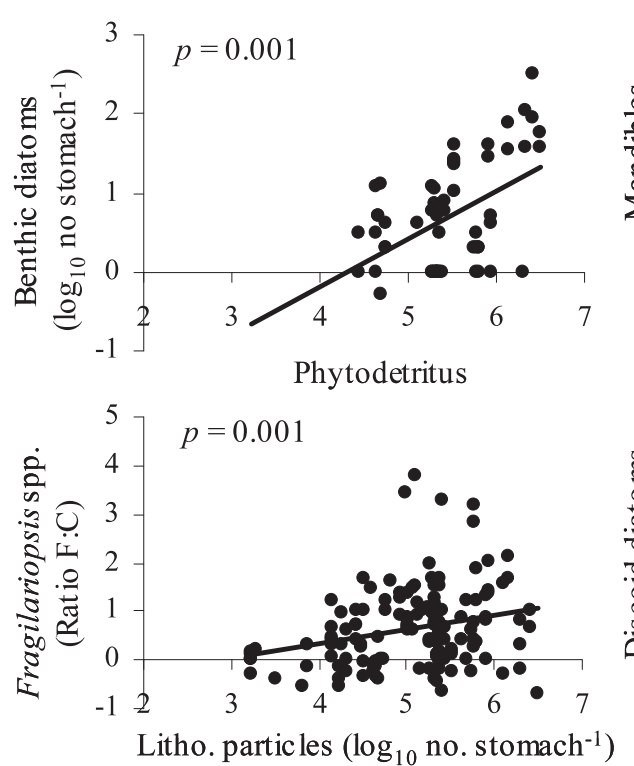

Litho. particles $\left(\log _{10}\right.$ no. stomach $\left.{ }^{-1}\right)$
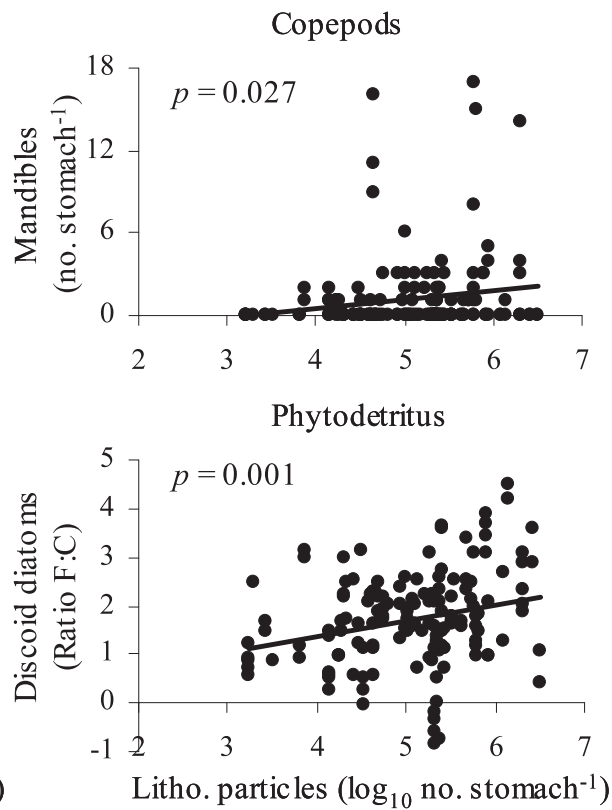

B
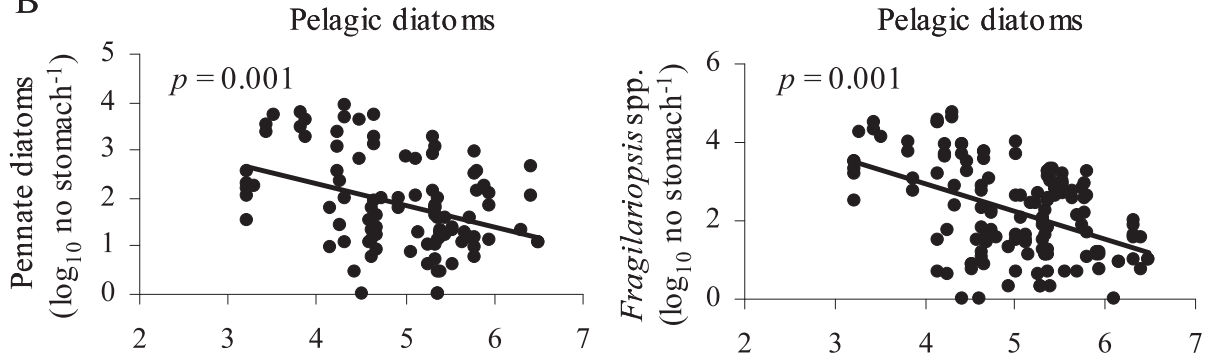

Pelagic diato ms
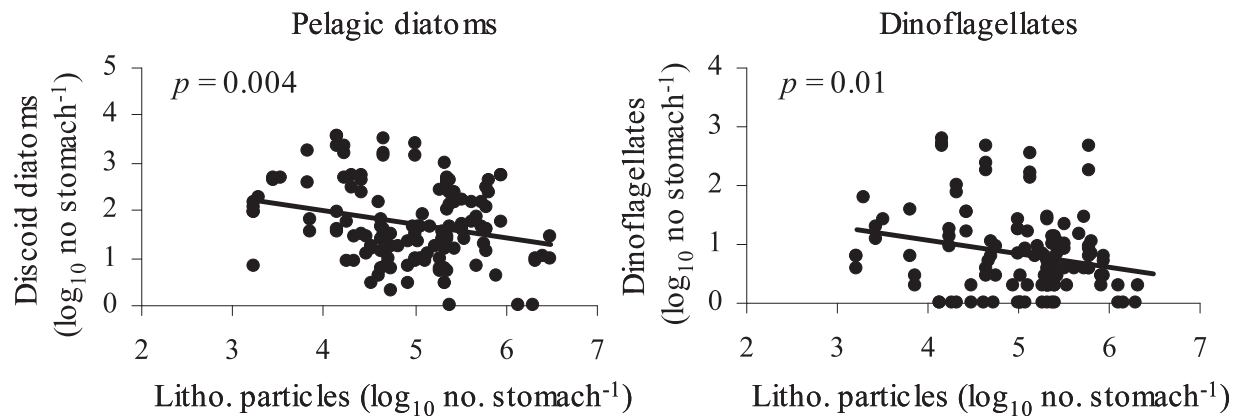

Fig. 9. Euphausia superba, krill stomach content identified under the microscope. (A) Food items showing a positive correlation with lithogenic (Litho.) particles. (B) Food items showing a negative correlation with lithogenic particles. Benthic diatom species: Cocconeis spp. and Grammatophora spp. The ratio of cell fragments (F) vs. complete cells (C) was used as an indicator of phytodetritus. Each dot represents one individual.

directly been measured in this study. However, we calculated that excretion rates could be as high as $0.17 \mathrm{nmol}$ iron $\mathrm{mg}^{-1}$ dry weight $\mathrm{d}^{-1}$, based on the fact that krill with a high stomach content of lithogenic particles contain $0.34 \pm$ $0.43 \mathrm{nmol}$ labile iron $\mathrm{mg}^{-1}$ dry weight $(n=5$, Fig. $10 \mathrm{~B})$ and about half of this ingested iron could be released in dissolved form (and a quarter each in assimilated and fecal pellet pools) as shown for copepods (Hutchins et al. 1995). If taking into account the large biomass concentrations of krill in the Scotia Sea (7400 mg dry weight $\mathrm{m}^{-2}$, Demer et al. 2007, assuming dry weight $=0.2 \times$ wet weight), this value leads to a total release of dissolved iron by krill returning from the seabed of $26 \mathrm{nmol} \mathrm{Fe} \mathrm{m} \mathrm{m}^{-2} \mathrm{~d}^{-1}$ if $\sim 2 \%$ of the total population migrated and $312 \mathrm{nmol} \mathrm{Fe} \mathrm{m}^{-2} \mathrm{~d}^{-1}$ if $20 \%$ of the population migrated daily.

The study of Tovar-Sanchez et al. (2007) suggests even higher iron release rates by krill of $0.5-17 \mathrm{nmol}$ iron $\mathrm{mg}^{-1}$ dry weight $d^{-1}$. However, these data represent particulate 


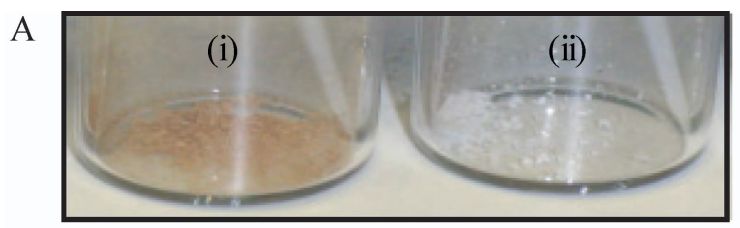

B

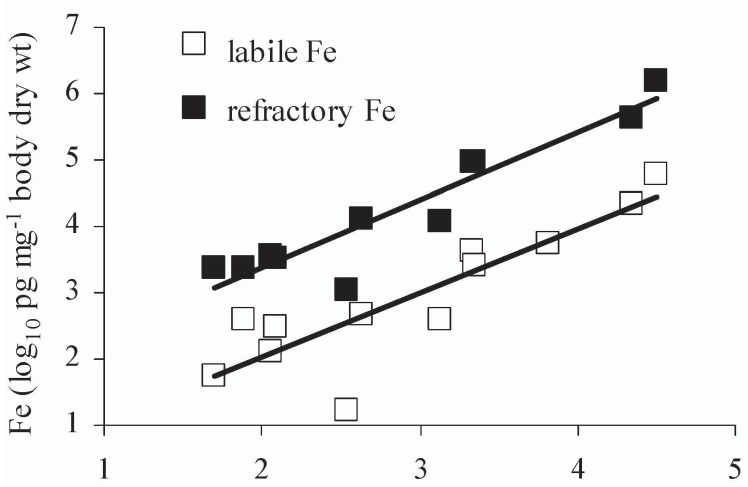

Lithogenic particles $\left(\log _{10}\right.$ no. $\mathrm{mg}^{-1}$ body dry wt)

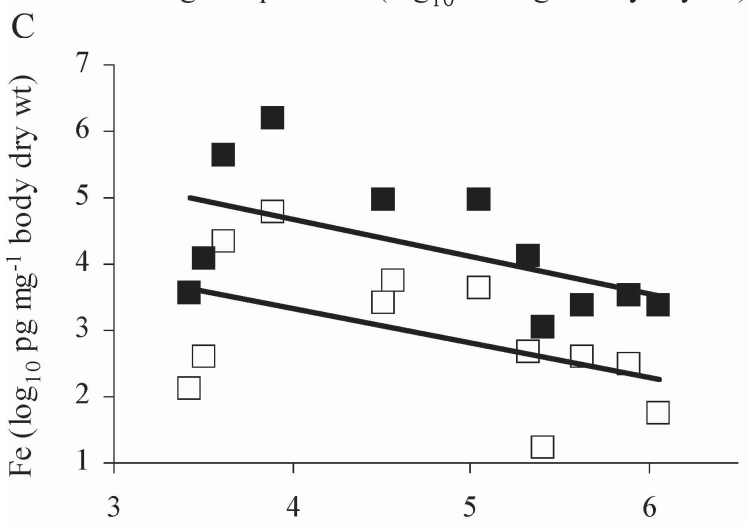

Food ( $\log _{10} \mu \mathrm{m}^{3} \mathrm{mg}^{-1}$ body dry wt)

D

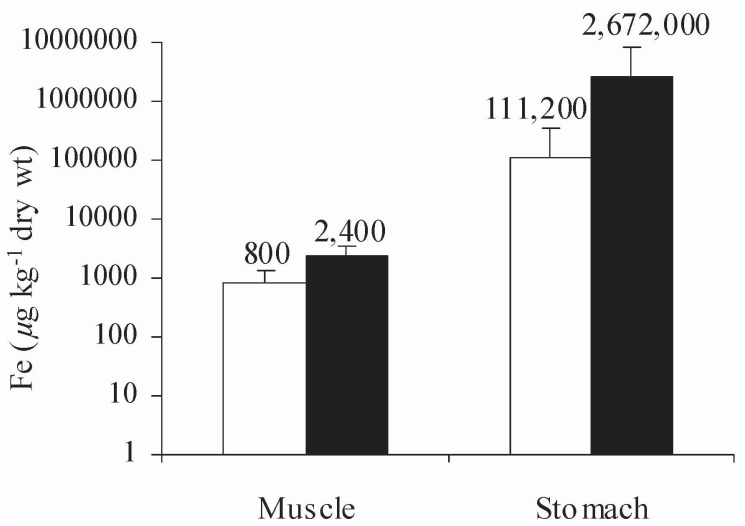

Fig. 10. Euphausia superba, iron concentrations in stomach and muscle. The krill were sampled at 12 stations in the Scotia Sea. (A) Stomach samples with high amount of lithogenic particles turned ochre during combustion, indicating the presence of $\mathrm{Fe}$ oxides (i). In contrast, white ash was derived from organic structures and biogenic silica (ii). (B) Correlation between amount of iron and number of lithogenic particles in krill stomachs, both normalized to body dry weight (refractory Fe: $y=1.0208 x+$ 1.3332, $R^{2}=0.876, p<0.001, n=11$; labile Fe: $y=0.9737 x+$ as well as dissolved iron fractions. We have subsequently measured dissolved iron excretion rates for krill sampled at seven stations north of South Georgia during January 2011. These gave a maximum value of $0.04 \mathrm{nmol}$ dissolved iron $\mathrm{mg}^{-1}$ dry weight $\mathrm{d}^{-1}$ based on 3-h incubations after capture (A. Atkinson and C. Schlosser unpubl. data). This is similar to values we calculate for stomachs with a moderate load of lithogenic particles based on Fig. 10B. Multiplied by the benthically feeding part of the population (2-20\% as above), this value amounts to 6-76 nmol dissolved iron $\mathrm{m}^{-2} \mathrm{~d}^{-1}$ brought into the top $200 \mathrm{~m}$. All of the three calculations concur that iron release by krill is a substantial input compared to values of 4 to $145 \mathrm{nmol}$ dissolved iron $\mathrm{m}^{-2} \mathrm{~d}^{-1}$ from other sources such as upwelling (de Baar et al. 1995; Blain et al. 2007; Pollard et al. 2009) or dust deposition (Tegen and Fung 1994; Mahowald et al. 1999; Moore et al. 2002).

The hypothesis that krill release dissolved iron after benthic feeding is supported by three separate observations: First, enzymatic digestion of food and a low $\mathrm{pH}$ within crustacean guts (Dall and Moriarty 1983) are ideal to solubilize iron from particles (Hutchins and Bruland 1994; Barbeau et al. 1996); second, the amount of labile iron in krill stomachs can be $>100$ times higher than what is required for their daily growth (assuming a growth rate of $\sim 1 \%$ of body mass $\mathrm{d}^{-1}$, Atkinson et al. 2006), suggesting that benthic feeding leads to a surplus of labile iron in krill stomachs. Third, iron pools that are not soluble during stomach passage might subsequently be released from fecal pellets through microbial degradation (Hutchins and Bruland 1994) or desorption from lithogenic particles (Blain et al. 2007) after pellet disintegration.

A role of krill in recycling iron within surface layers has been suggested before (Tovar-Sanchez et al. 2007; Nicol et al. 2010), but the fact that krill stomachs can contain up to 12 times more iron than the rest of the krill body points to krill as vector for "new" iron from the seabed. This is a fundamental distinction, because, however efficient recycling may be, sources of new iron are needed to activate a strong biological carbon pump (Blain et al. 2007; Pollard et al. 2009). Such input of new iron into surface waters is usually attributed to physical forces-vertical mixing, lateral flow, upwelling, and mineral dust deposition (de Baar et al. 1995; Moore et al. 2002; Lam et al. 2006). The large biomass of krill, and their interchange across a very strong vertical gradient in iron concentrations, suggests a role for krill in the iron cycle that has been unsuspected.

0.0812, $R^{2}=0.766, p<0.001, n=12$ ). (C) Correlation between amount of iron and food in krill stomachs, both normalized to body dry weight (refractory Fe: $y=-0.5626 x+6.9296, R^{2}=$ $0.2953, p=0.084, n=11$; labile Fe: $y=-0.5315 x+5.4642, R^{2}=$ $0.2323, p=0.113, n=12$ ). The total microscopically identifiable volume of food $\left(\mu \mathrm{m}^{3}\right)$ was calculated from counts and measurements of individual items in the stomach content. (D) Iron concentrations (mean $\pm 1 \mathrm{SD}$ ) in the stomach exceed that of muscle tissue by $2-3$ orders of magnitude. Labile iron accounts for $25 \% \pm 6 \%$ of total iron in the muscle and for $5 \% \pm 4 \%$ in the stomach. Mean values are given above each bar. 


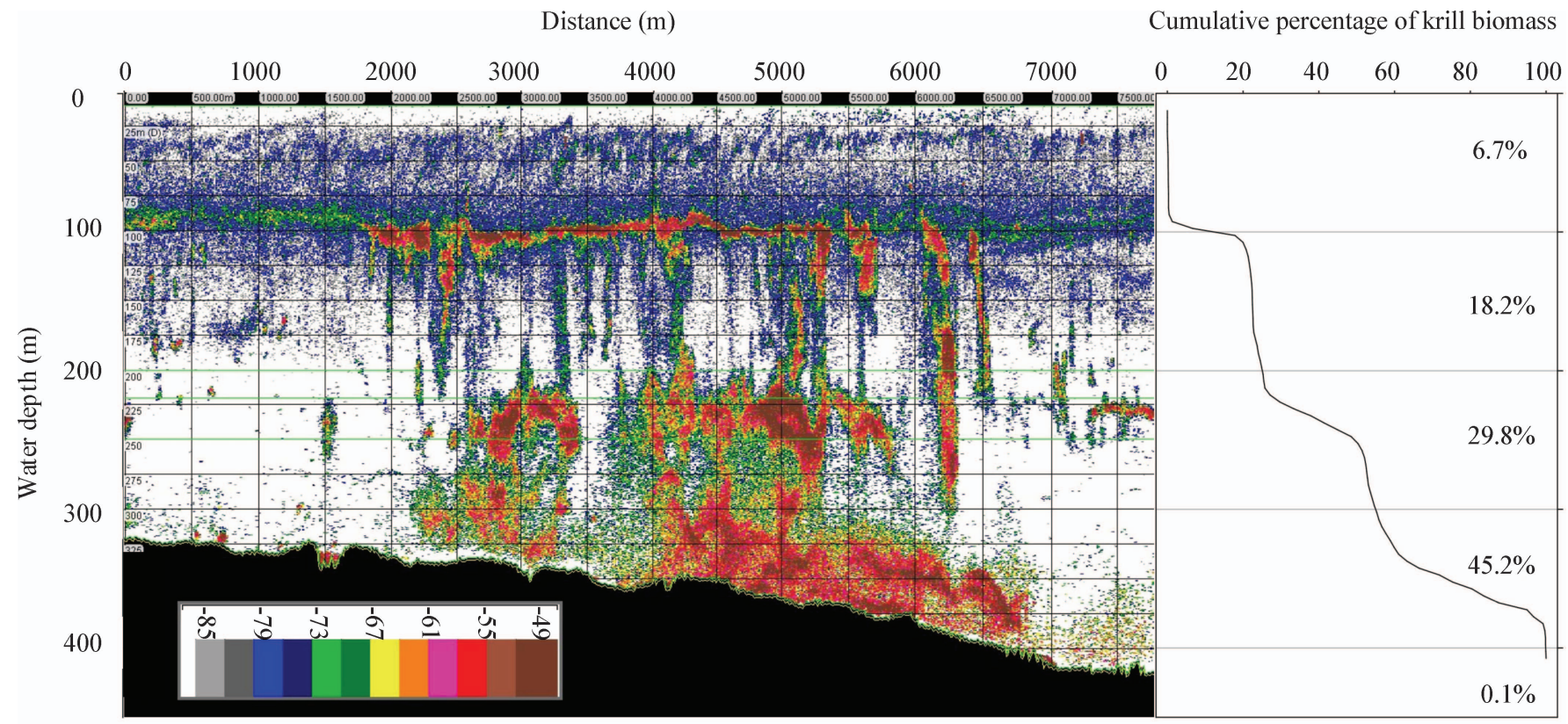

Volume backscattering strength $\mathrm{S}_{\mathrm{v}}$

Fig. 11. Euphausia superba, aggregation of high krill biomass at the seabed and in midwater layers to the NE of South Georgia $\left(54^{\circ} 7.5^{\prime} \mathrm{S} ; 35^{\circ} 25.6^{\prime} \mathrm{W}\right)$. The image represents volume backscattering strength $\left(\mathrm{S}_{\mathrm{v}}, \mathrm{dB}\right.$ re $\left.1 \mathrm{~m}^{-1}\right)$ at $120 \mathrm{kHz}$ over a $25-\mathrm{min}$ period $(17: 10 \mathrm{~h}$ to 17:35 h Greenwich Mean Time [GMT], 3 January 2011). Krill biomass was estimated from the $120-\mathrm{kHz}_{\mathrm{H}}$ data using a variable $\Delta \mathrm{S}_{\mathrm{v} 120-38} \mathrm{~dB}$ window identification technique (CCAMLR 2010).

Perspectives for future research-This study shows that, far from being exceptional, visits to the seabed are an important part of the life of adult krill with implications for the wider food web and biogeochemical cycles. However, we still need further investigations to resolve the dynamics of these feeding migrations and their quantitative aspects. Krill are subject to an expanding fishery; so one key question is what fraction of the population is missed by stock surveys of the upper layers? This requires simultaneous quantifications of krill densities at the seabed and in the water column above. Such studies will benefit from extended acoustics sampling depths, e.g., by using towed acoustic systems (Lawson et al. 2004) and digital cameras with sufficient image resolution to identify and enumerate krill at the seabed. Repeatedly sampling such large krill aggregations as seen in Fig. 11 might reveal if some krill live in "permanent benthic populations" (Brierley 2008) or return to the surface on a daily basis. Finally, sampling krill in good conditions directly from the seabed will allow budgeting of benthically derived food sources, calories, and trace metals.

Reports on bentho-pelagic aggregations and feeding at the seabed are not restricted to E. superba but include other euphausiid species also considered to be pelagic, e.g., Meganyctiphanes norvegica (Youngbluth et al. 1989; Schmidt 2010), Euphausia pacifica (Nakamura 1992; Taki 2006), and Euphausia vallentini (Hamame and Antezana 2010). Due to difficult access, epibenthic habitats might have been considerably undersampled in the past, especially at depth. However, with more frequent use of video systems and deep acoustics we will be in a better position to understand the role of epibenthic habitats for euphausiid species.

\section{Acknowledgments}

Special thanks to A. Clarke, J. Gutt, P. Tyler, D. Bowden, and D. Gerdes for providing unpublished information on E. superba at the seabed. We thank J. Roe, J. Watt, A. Prior, L. Jones, C. Charman, M. Belchier, M. Collins, K. Ross, and S. Clarke for sampling krill during their cruises. A. Milton and M. Patey gave technical support during trace metal analysis. We are grateful to V. Siegel and E. Pakhomov for supplying vertical krill distribution data to the "krillbase" dataset, and to H. Venables, E. Pakhomov, and two anonymous reviewers for constructive discussion of our results. The photographic survey off Terre Adélie was part of the International Polar Year project Census of Marine Life Collaborative (CEAMARC voyage 1). This study was funded by the Natural Environment Research Council grant AFI5/09 and the Discovery 2010 Programme of the British Antarctic Survey.

\section{References}

Antezana, T. 2009. Species-specific patterns of diel migration into the oxygen minimum zone by euphausiid in the Humboldt Current Ecosystem. Prog. Oceanogr. 83: 228-236, doi:10. 1016/j.pocean.2009.07.039

Atkinson, A., S. B. Schnack-Schiel, P. Ward, and V. Marin. 1997. Regional differences in the life cycle of Calanoides acutus (Copepoda: Calanoida) within the Atlantic sector of the Southern Ocean. Mar. Ecol. Prog. Ser. 150: 99-111, doi:10.3354/meps150099

, V. Siegel, E. Pakhomov, M. J. Jessopp, and V. Loeb. 2009. A re-appraisal of the total biomass and annual production of Antarctic krill. Deep-Sea Res. I 56: 727-740, doi:10.1016/j.dsr.2008.12.007

— AND OTHERs. 2006. Natural growth rates in Antarctic krill (Euphausia superba): II. Predictive models based on food, temperature, body length, sex, and maturity stage. Limnol. Oceanogr. 51: 973-987, doi:10.4319/1o.2006.51.2.0973 
, AND OTHERS. 2008. Oceanic circumpolar habitats of Antarctic krill. Mar. Ecol. Prog. Ser. 362: 1-23, doi:10.3354/ meps07498

Barbeau, K., J. W. Moffett, D. A. Caron, P. L. Croot, and D. L. ERDNER. 1996. Role of protozoan grazing in relieving iron limitation of phytoplankton. Nature 380: 61-64, doi:10.1038/ $380061 \mathrm{a} 0$

Barrera-Oro, E. R., and R. J. Casaux. 1990. Feeding selectivity in Notothenia neglecta, Nybelin, from Potter Cove, South Shetlands Islands, Antarctica. Antarct. Sci. 2: 207-213.

Benoit-Bird, K. J., And W. W. L. Au. 2006. Extreme diel horizontal migrations by a tropical nearshore resident micronekton community. Mar. Ecol. Prog. Ser. 319: 1-14, doi:10.3354/meps319001

Blain, S., AND OTHERS. 2007. Effect of natural iron fertilization on carbon sequestration in the Southern Ocean. Nature 446: 1070-1074, doi:10.1038/nature05700

Brierley, A. S. 2008. Antarctic ecosystem: Are deep krill ecological outliers or portents of a paradigm shift? Curr. Biol. 18: 252-254, doi:10.1016/j.cub.2008.01.022

Bruland, K. W., AND M. C. Lohan. 2006. Controls of trace metals in seawater, p. 23-47. In H. Elderfield [ed.], The oceans and marine geochemistry. Elsevier.

Burns, J. M., AND OTHERS. 2004. Winter habitat use and foraging behavior of crabeater seals along the Western Antarctic Peninsula. Deep-Sea Res. II 51: 2279-2303, doi:10.1016/ j.dsr2.2004.07.021

Christie, W. W. 1982. Lipid analyses, 2nd ed. Pergamon.

Clarke, A., H. J. Griffiths, D. K. A. Barnes, M. P. Meredith, And S. M. Grant. 2009. Spatial variant in seabed temperatures in the Southern Ocean: Implications for benthic ecology and biogeography. J. Geophys. Res. 114: G03003, doi:10. 1029/2008JG000886

- AND P. A. TYLER. 2008. Adult Antarctic krill feeding at abyssal depths. Curr. Biol. 18: 282-285, doi:10.1016/j.cub.2008.01.059

Conle, K. H., M. R. Gordon, and X. Wang. 2005. The distribution and behavior of dissolved and particulate iron and zinc in the Ross Sea and Antarctic circumpolar current along $170^{\circ}$ W. Deep-Sea Res. I 52: 295-318, doi:10.1016/ j.dsr.2004.09.008

Coetzee, J. 2000. Use of a shoal analysis and patch estimation system (SHAPES) to characterize sardine schools. Aquat. Living Resour. 13: 1-10, doi:10.1016/S0990-7440(00)00139-X

Commission for the Conservation of Antarctic Marine Living ResourCes (CCAMLR). 2010. Report of the fifth meeting of the subgroup on acoustic survey and analysis methods. SCCAMLR-XXIX/6.

Dall, W., and D. J. W. Moriarty. 1983. Functional aspects of nutrition and digestion, p. 215-261. In L. H. Mantel [ed.], The biology of Crustacea, v. 5. Academic Press.

DALY, K. 1990. Overwintering development, growth, and feeding of larval Euphausia superba in the Antarctic marginal ice zone. Limnol. Oceanogr. 35: 1564-1576, doi:10.4319/lo.1990.35.7.1564 , AND M. C. Macaulay. 1991. Influence of physical and biological mesoscale dynamics on the seasonal distribution and behavior of Euphausia superba in the Antarctic marginal ice zone. Mar. Ecol. Prog. Ser. 79: 37-66, doi:10.3354/meps079037

Dearborn, J. H., K. C. Edwards, and D. B. Fratt. 1991. Diet, feeding behavior, and surface morphology of the multi-armed Antarctic sea star Labidiaster annulatus (Echinodermata: Asteroidea). Mar. Ecol. Prog. Ser. 77: 65-84, doi:10.3354/ meps077065

, G. Hendler, and K. C. Edwards. 1996. The diet of Ophiosparte gigas (Echinodermata: Ophiuroidea) along the Antarctic Peninsula, with comments on its taxonomic status. Polar Biol. 16: 309-320. de BaAr, H. J. W., J. T. M. De Jong, D. C. E. Bakker, B. M Löscher, C. Veth, U. Bathmann, and V. Smetacek. 1995. Importance of iron for plankton blooms and carbon dioxide drawdown in the Southern Ocean. Nature 373: 412-415, doi:10.1038/373412a0

De La Rocha, C. L. 2006. The biological pump, p. 83-111. In H. Elderfield [ed.], The oceans and marine geochemistry. Elsevier.

Demer, D. A. 2004. An estimate of error for the CAMLR 2000 survey estimate of krill biomass. Deep-Sea Res. II 51: 1237-1251.

- A. M. Cossio, And C. S. Reiss. 2007. Section 3.21 of SCCAMLR-XXVI, Report of the 26th meeting of the Scientific Committee, Hobart, Australia, 22-26 October 2007.

—, AND R. P. Hewitt. 1995. Bias in acoustic biomass estimates of Euphausia superba due to diel vertical migration. Deep-Sea Res. I 42: 455-475, doi:10.1016/0967-0637(94) E0005-C

Fach, B. A., E. E. Hofmann, And E. J. Murphy. 2006. Transport of Antarctic krill (Euphausia superba) across the Scotia Sea. Part II: Krill growth and survival. Deep-Sea Res. I 53: 1011-1043, doi:10.1016/j.dsr.2006.03.007

Fratt, D. B., AND J. H. Dearborn. 1984. Feeding biology of the Antarctic brittle star Ophionotus victoriae (Echinodermata: Ophiuroidea). Polar Biol. 3: 127-139, doi:10.1007/ BF00442644

Godlewska, M. 1996. Vertical migrations of krill (Euphausia superba Dana). Pol. Arch. Hydrobiol. 14: 9-63.

Green, J. A., I. L. Boyd, A. J. Woakes, N. L. Warren, and P. J. ButLer. 2005. Behavioral flexibility during year-round foraging in macaroni penguins. Mar. Ecol. Prog. Ser. 296: 183-196, doi:10.3354/meps296183

Gutt, J., AND V. Siegel. 1994. Benthopelagic aggregations of krill (Euphausia superba) on the deeper shelf of the Weddell Sea (Antarctic). Deep-Sea Res. I 41: 169-178, doi:10.1016/09670637(94)90031-0

Hamame, M., And T. Antezana. 2010. Vertical diel migration and feeding of Euphausia vallentini within southern Chilean fjords. Deep-Sea Res. II 57: 642-651, doi:10.1016/j.dsr2.2009.10.013

Hamner, W. M., P. P. Hamner, S. W. Strand, and R. W. Gilmer. 1983. Behavior of Antarctic krill, Euphausia superba - chemoreception, feeding, schooling, and molting. Science 220: 433-435, doi:10.1126/science.220.4595.433

Haney, J. F. 1988. Diel patterns of zooplankton behavior. Bull. Mar. Sci. 43: 583-603.

Haupt, F., M. Stockenreiter, E. S. Reichwaldt, M. BaumgartNer, W. Lampert, M. Boersma, and H. Stibor. 2010. Upward phosphorus transport by Daphnia diel vertical migration. Limnol. Oceanogr. 55: 529-534, doi:10.4319/lo.2009.55.2.0529

HAYS, G. C. 2003. A review of the adaptive significance and ecosystem consequences of zooplankton diel vertical migrations. Hydrobiologia 503: 163-170, doi:10.1023/B:HYDR. 0000008476.23617.b0

Hewitt, R. P., AND others. 2004. Biomass of Antarctic krill in the Scotia Sea in January/ February 2000 and its use in revising an estimate of precautionary yield. Deep-Sea Res. II 51: 1215-1236.

Huntley, M. E., AND M. Zhou. 2004. Influence of animals on turbulence in the sea. Mar. Ecol. Prog. Ser. 273: 65-79, doi:10.3354/meps273065

Hutchins, D. A., AND K. W. BRuland. 1994. Grazer-mediated regeneration and assimilation of $\mathrm{Fe}, \mathrm{Zn}$, and $\mathrm{Mn}$ from planktonic prey. Mar. Ecol. Prog. Ser. 110: 259-269, doi:10.3354/ meps110259

- W.-X. WANG, ANd N. S. Fisher. 1995. Copepod grazing and the biogeochemical fate of diatom iron. Limnol. Oceanogr. 40: 989-994, doi:10.4319/lo.1995.40.5.0989 
Ihaka, R., and R. Gentleman. 1996. R: A language for data analysis and graphics. J. Comput. Graph. Stat. 5: 299-314, doi:10.2307/1390807

Karlson, K., and U. BÅmstedt. 1994. Planktivorous predation on copepods - evaluation of mandible remains in predator guts as a quantitative estimate of predation. Mar. Ecol. Prog. Ser. 108: 79-89, doi: $10.3354 /$ meps 108079

Kato, A., A. Yoshioka, and K. Sato. 2009. Foraging behavior of Adélie penguins during incubation period in Lützow-Holm Bay. Polar Biol. 32: 181-186, doi:10.1007/s00300-008-0518-9

Kawaguchi, K., S. Ishikawa, and O. Matsuda. 1986. The overwintering of Antarctic krill (Euphausia superba Dana) under the coastal fast ice off the Ongul Islands in LützowHolm Bay, Antarctica. Mem. Natl. Inst. Polar Res. (special issue) 44: 67-85.

Kawaguchi, S., and S. Nicol. 2007. Learning about Antarctic krill from the fishery. Antarct. Sci. 19: 219-230, doi:10.1017/ S0954102007000296

-, R. Kilpatrick, L. Roberts, R. A. King, and S. Nicol. In press. Ocean-bottom krill sex. J. Plankton Res. doi:10.1093/ plankt/fbr006

KILs, U. 1981. Swimming behavior, swimming performance and energy balance of Antarctic krill Euphausia superba. Biomass Sci. Ser. 3: 1-122.

Klevjer, T. A., G. A. Tarling, and S. Fielding. 2010. Swarm characteristics of Antarctic krill Euphausia superba relative to the proximity of land during summer in the Scotia Sea. Mar. Ecol. Prog. Ser. 409: 157-170, doi:10.3354/meps08602

Kokubun, N., A. Takahashi, Y. Mori, S. Watanabe, and H.-C. SHIN. 2010. Comparison of diving behavior and foraging habitat use between chinstrap and gentoo penguins breeding in the South Shetland Islands, Antarctica. Mar. Biol. 157: 811-825, doi:10.1007/s00227-009-1364-1

Korb, R. E., M. J. Whitehouse, A. Atkinson, and S. E. Thorpe. 2008. Magnitude and maintenance of the phytoplankton bloom at South Georgia: A naturally iron-replete environment. Mar. Ecol. Prog. Ser. 368: 75-91, doi:10.3354/meps07525

Lam, P. J., J. K. B. Bishop, C. C. Henning, M. A. Marcus, G. A. WAYChUNAS, AND I. Y. Fung. 2006. Wintertime phytoplankton bloom in the subarctic Pacific supported by continental margin iron. Glob. Biogeochem. Cycles 20: GB1006, doi:10.1029/2005GB002557

Lancraft, T. M., J. J. Torres, and T. L. Hopkins. 1989. Micronekton and macrozooplankton in the open waters near Antarctic ice edge zones (AMERIEZ 1983 and 1986). Polar Biol. 9: 225-233, doi:10.1007/BF00263770

Lascara, C. M., E. E. Hofmann, R. M. Ross, and L. B. Quetin. 1999. Seasonal variability in the distribution of Antarctic krill, Euphausia superba, west of the Antarctic Peninsula. Deep-Sea Res. I 51: 951-984, doi:10.1016/S0967-0637(98)00099-5

LAVERY, T. J., AND OTHERS. 2010. Iron defecation by sperm whales stimulates carbon export in the Southern Ocean. Proc. R. Soc. Lond. B 227: 3527-3531, doi:10.1098/rspb.2010.0863

Lawson, G. L., P. H. Wiebe, C. J. Ashian, S. M. Gallanger, C. S. Davis, AND J. D. Warren. 2004. Acoustically-inferred zooplankton distribution in relation to hydrography west of the Antarctic Peninsula. Deep-Sea Res. 51: 2041-2072, doi:10.1016/j.dsr2.2004.07.022

Ligowski, R. 2000. Benthic feeding by krill, Euphausia superba Dana, in coastal waters off West Antarctica and in Admiralty Bay, South Shetland Islands. Polar Biol. 23: 619-625, doi:10.1007/s003000000131

Longhurst, A. R., And W. G. Harrison. 1989. The biological pump - profiles of plankton production and consumption in the upper ocean. Prog. Oceanogr. 22: 47-123, doi:10.1016/ 0079-6611(89)90010-4
Mahowald, N., AND others. 1999. Dust sources and deposition during the last glacial maximum and current climate: A comparison of model results with paleodata from ice cores and marine sediment. J. Geophys. Res. 104: 15895-15916, doi:10.1029/1999JD900084

Main, C. E., And M. A. Collins. 2011. Diet of the Antarctic starry skate Amblyraja georgiana (Rajida, Chondrichthyes) at South Georgia (Southern Ocean). Polar Biol 34: 389-396, doi:10.1007/s00300-010-0894-9

Marin, V. H., E. Brinton, and M. Huntley. 1991. Depth relationships of Euphausia superba eggs, larvae and adults near the Antarctic Peninsula, 1986-87. Deep-Sea Res. 38: $1241-1249$.

MARR, J. W. S. 1962. The natural history and geography of the Antarctic krill (Euphausia superba Dana). Discov. Rep. 32: 33-464.

Mauchline, J. 1998. The biology of calanoid copepods. Adv. Mar. Biol. 33: 1-710, doi:10.1016/S0065-2881(08)60234-5

Moore, J. K., S. C. Doney, D. M. Glover, and I. Y. Fung. 2002. Iron cycling and nutrient-limitation patterns in surface waters of the world ocean. Deep-Sea Res. I 49: 463-507, doi:10.1016/ S0967-0637(01)00074-7

Murphy, E. J. 1995. Spatial structure of the Southern Ocean ecosystem: Predator-prey linkages in Southern Ocean food webs. J. Anim. Ecol. 64: 333-347, doi:10.2307/5895

NAKAMURA, T. 1992. Recent aspects of krill fishing grounds off Joban-Kashim area in relation to warming tendency. Bull. Jpn. Soc. Fish. Oceanogr. 56: 155-157.

NICOL, S. 2006. Krill, currents, and sea ice: Euphausia superba and its changing environment. BioScience 56: 111-120, doi:10. 1641/0006-3568(2006)056[0111:KCASIE]2.0.CO;2

, A. Bowie, S. Jarman, D. Lannuzel, K. M. Meiners, and P. VAN Der Merwe. 2010. Southern Ocean iron fertilization by baleen whales and Antarctic krill. Fish Fish. 11: 203-209.

, J. Kitchener, R. King, G. W. Hosie, And W. K. DE LA MARE. 2000. Population structure and condition of Antarctic krill (Euphausia superba) off East Antarctica $\left(80-50^{\circ} \mathrm{E}\right)$ during the austral summer of 1995/96. Deep-Sea Res. II 47: 2489-2517, doi:10.1016/S0967-0645(00)00033-3

Ohman, M. D. 1988. Behavioral responses of zooplankton to predation. Bull. Mar. Sci. 43: 530-550.

Olaso, I., M. Rauschert, and C. De Broyer. 2000. Trophic ecology of the family Artedidraconidae (Pisces: Osteichthyes) and its impact on the eastern Weddell Sea benthic system. Mar. Ecol. Prog. Ser. 194: 143-158, doi:10.3354/meps194143

Paкномоv, E. A. 1997. Feeding and exploitation of the food supply by demersal fishes in the Antarctic part of the Indian Ocean. J. Ichthyol. 37: 360-380.

-1998. Diet of two Antarctic dragonfish (Pisces: Bathydraconidae) from the Indian sector of the Southern Ocean. Antarct. Sci. 10: 55-61, doi:10.1017/S095410209800008X

PeArre, S. 2003. Eat and run? The hunger/ satiation hypothesis in vertical migration: History, evidence and consequences. Biol. Rev. 78: 1-79, doi:10.1017/S146479310200595X

Perissinotto, R., and E. A. Pakhomov. 1996. Gut evacuation rates and pigment destruction in the Antarctic krill Euphausia superba. Mar. Biol. 125: 47-54, doi:10.1007/BF00350759

Piatkowski, U., P. G. Rodhouse, M. G. White, D. G. Bone, and C. Symon. 1994. Nekton community of the Scotia Sea as sampled by the RMT 25 during austral summer. Mar. Ecol. Prog. Ser. 112: 13-28, doi:10.3354/meps 112013

Piepenburg, D., M. K. Schmid, and D. Gerdes. 2002. The benthos off King George Island (South Shetland Islands, Antarctica): Further evidence for a lack of a latitudinal biomass cline in the Southern Ocean. Polar Biol. 25: 146158. 
Planguette, H., G. R. Fones, P. J. Statham, and P. J. Morris. 2009. Origin of iron and aluminium in large particles $(>53 \mu \mathrm{m})$ in the Crozet region, Southern Ocean. Mar. Chem. 115: 31-42, doi:10.1016/j.marchem.2009.06.002

Pollard, T. R., AND others. 2009. Southern Ocean deep-water carbon export enhanced by natural iron fertilization. Nature 457: 577-580, doi: $10.1038 /$ nature 07716

Prince, P. A., AND M. Jones. 1992. Maximum dive depths attained by South Georgia diving petrel Pelecanoides georgicus at Bird Island, South Georgia. Antarct. Sci. 4: 433434.

Quetin, L. B., R. M. Ross, T. K. Frazer, and K. L. Haberman. 1996. Factors affecting distribution and abundance of zooplankton, with an emphasis on Antarctic krill, Euphausia superba. Ant. Res. Ser. 70: 357-371.

San Vicente, C., A. Ramos, And J. C. Sorbe. 2006. Suprabenthic euphausiids and mysids from the South Shetland Islands and the Bransfield Strait, Southern Ocean (BENTART-95 cruise). Polar Biol. 29: 211-222, doi:10.1007/s00300-005-0041-1

Sardou, J., M. Etienne, and V. Andersen. 1996. Seasonal abundance and vertical distributions of macroplankton and micronekton in the Northwestern Mediterranean Sea. Oceanol. Acta 19: 645-656.

Schmidt, K. 2010. Food and feeding in Northern krill (Meganyctiphanes norvegica SARS). Adv. Mar. Biol. 57: 127-171, doi:10.1016/B978-0-12-381308-4.00005-4

, A. Atrinson, K.-J. Petzke, M. Voss, and D. W. Pond. 2006. Protozoans as a food source for Antarctic krill: Complementary insights from stomach content, fatty acids, and stable isotopes. Limnol. Oceanogr. 51: 2409-2427, doi:10.4319/1o.2006.51.5.2409

Shirihai, H. 2002. A complete guide to Antarctic wildlife. Alula Press.

Siegel, V. 2005. Distribution and population dynamics of Euphausia superba: Summary of recent findings. Polar Biol. 29: 1-22, doi:10.1007/s00300-005-0058-5

Smith, C. R., and D. J. DeMaster. 2008. Preface and brief synthesis for the FOODBANCS volume. Deep-Sea Res. II 55: 2399-2403, doi:10.1016/j.dsr2.2008.08.001

- S. Mincks, And D. J. DeMaster. 2006. A synthesis of bentho-pelagic coupling on the Antarctic shelf: Food banks, ecosystem inertia and global climate change. Deep-Sea Res. II 53: 875-894, doi:10.1016/j.dsr2.2006.02.001

Smith, K. L., JR., AND others. 2007. Free-drifting icebergs: Hot spots of chemical and biological enrichment in the Weddell Sea. Science 317: 478-482, doi:10.1126/science.1142834

Song, K. H., AND V. T. BReslin. 1999. Accumulation and transport of sediment metals by vertically migrating opossum shrimp, Mysis relicta. J. Great Lakes Res. 25: 429-442, doi:10.1016/S0380-1330(99)70752-5

Staniland, I. J., K. Reid, and I. L. Boyd. 2004. Comparing individual and spatial influences on foraging behavior in Antarctic fur seals Arctocephalus gazella. Mar. Ecol. Prog Ser. 275: 263-274, doi:10.3354/meps 275263
Takahashi, A., M. J. Dunn, P. N. Trathan, K. Sato, Y. Naitoo, AND J. P. Croxall. 2003. Foraging strategies of chinstrap penguins at Signy Island, Antarctica: Importance of benthic feeding on Antarctic krill. Mar. Ecol. Prog. Ser. 250: 279-289, doi:10.3354/meps250279

, N. Konubun, Y. Mori, and H.-C. Shin. 2008. Krill feeding behavior of gentoo penguins as shown by animalborne camera loggers. Polar Biol. 31: 1291-1294, doi:10.1007/ s00300-008-0502-4

TAKAHASHI, M. 1983. Trophic ecology of demersal fish community north of the South Shetland Islands, with notes on the ecological role of krill. Mem. Natl. Inst. Polar Res. 23: 183-192.

- AND T. Iwami. 1997. The summer diet of demersal fish at the South Shetland Islands. Antarct. Sci. 9: 407-413, doi:10.1017/S0954102097000527

TAKI, K. 2006. Studies on fishers and life history of Euphausia pacifica HANSEN off northeastern Japan. Bull. Fish. Res. Agency 18: 41-165.

, T. Yabuki, Y. Noiri, T. Hayashi, And M. Naganobu. 2008. Horizontal and vertical distribution and demography of euphausiids in the Ross Sea and its adjacent waters in 2004/ 2005. Polar Biol. 31: 1343-1356, doi:10.1007/s00300-008-0472-6

TARgett, T. E. 1981. Trophic ecology and structure of coastal Antarctic fish communities. Mar. Ecol. Prog. Ser. 4: 243-263, doi:10.3354/meps004243

TARling, G. A., AND OTHERs. 2009. Variability and predictability of Antarctic krill swarm structure. Deep-Sea Res. I 56: 1994-2012, doi:10.1016/j.dsr.2009.07.004

Tegen, I., AND I. Y. Fung. 1994. Modeling of mineral dust in the atmosphere: Sources, transport, and optical thickness. J. Geophys. Res. 99: 22897-22914, doi:10.1029/94JD01928

Tovar-Sanchez, A., C. M. Duarte, S. Hernández-León, and S. A. Sañudo-Wilhelmy. 2007. Krill as a central node for iron cycling in the Southern Ocean. Geophys. Res. Lett. 34: L11601, doi:10.1029/2006GL029096

Watwood, S. L., P. J. O. Miller, M. Johnson, P. T. Madsen, and P. L. TYACK. 2006. Deep-diving foraging behavior of sperm whales (Physeter macrocephalus). J. Anim. Ecol. 75: 814-825, doi:10.1111/j.1365-2656.2006.01101.x

Youngbluth, M. J., T. G. Bailey, P. J. Davoll, C. A. Jacoby, P. I. Blades-Eckelbarger, and C. A. Griswold. 1989. Fecal pellet production and diel migratory behavior by the euphausiid Meganyctiphanes norvegica affect benthic-pelagic coupling. Deep-Sea Res. 36: 1491-1501.

Zhou, M., And R. D. Dorland. 2004. Aggregation and vertical migration behavior of Euphausia superba. Deep-Sea Res. II 51: 2119-2137, doi:10.1016/j.dsr2.2004.07.009

Associate editor: Michael R. Landry

Received: 14 September 2010 Accepted: 29 March 2011 Amended: 18 April 2011 